\title{
Red Alder-Conifer Stands in Alaska: An Example of Mixed Species Management to Enhance Structural and Biological Complexity
}

\author{
Robert L. Deal ${ }^{1, *}$, Ewa H. Orlikowska ${ }^{2}$, David V. D'Amore ${ }^{3}$ and Paul E. Hennon ${ }^{3}$ \\ 1 USDA Forest Service, Pacific Northwest Research Station, 620 SW Main Street, Portland, OR 97205, USA \\ 2 School for Forest Management, Swedish University of Agricultural Sciences (SLU), Box 43, \\ 73921 Skinnskatteberg, Sweden; ewa.orlikowska@slu.se \\ 3 USDA Forest Service, Pacific Northwest Research Station, 11175 Auke Lake Way, Juneau, AK 99801, USA; \\ ddamore@fs.fed.us (D.V.D.); nootkatin@gmail.com (P.E.H.) \\ * Correspondence: rdeal@fs.fed.us; Tel.: +1-503-808-2015
}

Academic Editor: Timothy A. Martin

Received: 30 January 2017; Accepted: 14 April 2017; Published: 21 April 2017

\begin{abstract}
There is worldwide interest in managing forests to improve biodiversity, enhance ecosystem services and assure long-term sustainability of forest resources. An increasingly important goal of forest management is to increase stand diversity and improve wildlife and aquatic habitat. Well-planned silvicultural systems containing a mixture of broadleaf-conifer species have potential to enhance stand diversity and provide other ecosystem services earlier than typical even-aged conifer plantations. Here, we use the example of mixed Sitka spruce/western hemlock and red alder in young, managed stands in southeast Alaska to achieve these goals. We briefly describe the silvics of Sitka spruce, western hemlock and red alder plantations as pure conifer stands or pure broadleaf stands. Then, we synthesize studies of mixed red alder-Sitka spruce/western hemlock stands in southeast Alaska and present their potential for improving stand structural complexity, biodiversity and other ecosystem services over pure conifer forests. Finally, we discuss some of the opportunities and potential tradeoffs for managing mixed broadleaf-conifer stands for providing a number of natural resources and the influence of these broadleaf-conifer forests on ecosystem linkages and processes.
\end{abstract}

Keywords: conifer plantations; broadleaf-conifer stands; ecosystem services; forest management; Alaska

\section{Introduction}

Ecosystem services include a broad suite of social and ecological benefits provided by forest ecosystems including values that are often overlooked in traditional forest management decisions. Ecosystem services has emerged as a way of framing and describing the comprehensive set of benefits that people receive from nature [1-3]. Worldwide, there is an increasing focus on providing forest resources for social and economic sustainability while maintaining ecological integrity through forest management. Such strategies include developing late-successional stand characteristics, enhancing biodiversity in younger forests, retaining aquatic ecosystem integrity, water quality and wildlife habitat for ungulates and small mammals [4-7]. Forest management strategies that create more complex forests may also provide a broader range of ecosystem services than plantation forestry. This is particularly relevant for regions where plantations were traditionally managed for simple species composition but now need to consider a broader range of natural resources beyond simply timber production [8-10].

Many managed forest plantations intentionally contain single species compositions, often even-aged conifer stands that are managed on relatively short rotations with a focus on wood 
production [11,12]. There are some advantages to short rotation, single species compositions including better understanding of stand dynamics of individual species, ability to produce uniform wood on relatively short rotations and greater certainty of forest growth, yield and wood production $[11,13,14]$. Fast growing pine stands in the southern USA can reach rotation age in 25-30 years $[12,15]$ and Pinus radiata (D. Don) plantations in New Zealand can be harvested in 20 years $[16,17]$ and in 18-25 years in Chile [18]. However, there are a number of tradeoffs in single-species stands that are primarily managed for wood production. These uniform conifer plantations have simple tree height and diameter distributions and forest structures that often lead to reduced plant diversity and abundance, compromised wildlife and aquatic habitats and lower aesthetic values $[7,8,19,20]$. Therefore, reconciling the economic benefits of wood production with compromises in biodiversity is needed to inform management for multiple resource values.

Multiple-species stands have greater diversity of native tree and plant species, generally more complex forest structures than single species plantations, and multi-species forests provide many important ecosystem services [10,21]. Mixed broadleaf-conifer stands often provide a greater layer of complexity in tree height and diameter distribution than single species plantations. Additionally, including nitrogen-fixing tree species in mixed stands have a positive, significant effect on the diameter growth rate of non-fixing species [22]. Tree species diversity [23], stratified canopy of mixed stands as well as inclusion of the nitrogen-fixing species have been associated with higher stand-level productivity in mix-species plantations [24]. Previous studies in Britain and Ireland indicated that mixed tree species plantation forests can support higher biodiversity than similar monoculture forests [25,26]. Results from Sweden [27] showed that transforming spruce monocultures into spruce-birch mixtures provided gains in the biodiversity of many taxonomic groups, and that these biodiversity gains can be amplified when other forest management techniques (e.g., rotation length, retained Large Woody Debris-LWD) were incorporated. In central Europe, mixtures of European beech (Fagus sylvatica L.) and Norway spruce (Picea abies (L.) H. Karst.) have been managed together to enhance the resilience of the entire stand through nutrient cycling and soil remediation [28]. However, the specific benefits are still being investigated and while uncertainty regarding the benefits of these admixtures may persist, there is good evidence for the short-term potential value in these stands. Spruce growth can be improved in mixed stands with beech compared to pure stands on similar substrates [29], and Pretzsch et al. [30] reported an accelerated growth of spruce by beech admixtures on poor sites. These results agree with a meta-analysis of boreal and northern temperate forests, which found that mixed tree species were as productive as monoculture forests, while having increased resistance to pest damage over monoculture forests [31].

If deliberate red alder regeneration or other hardwood species such as birch could be incorporated into present harvest plans, managers might be able to trigger the positive benefits of alder or birch and improve structure and function of young forests. In this paper, we first briefly describe some of the silvics of common tree species in the coastal region of the Pacific Northwest including Sitka spruce (Picea sitchensis (Bong.) Carr.), western hemlock (Tsuga heterophylla (Raf. Sarg.), and red alder (Alnus rubra (Bong.)). Secondly, we present and explain their development as pure conifer or pure alder stands. Thirdly, we synthesize a set of case studies of mixed red alder-conifer stands in southeast Alaska and the potential of these mixed broadleaf-conifer stands for improving stand structural complexity, biodiversity and other ecosystem services. Finally, we discuss some opportunities for managing mixed broadleaf-conifer stands contrasted with predominantly conifer plantations and the potential benefits of these mixed alder-conifer forests for providing a number of important ecosystem services.

\section{Distribution of Species}

\subsection{Range and Habitat of Sitka Spruce}

Sitka spruce, the largest of the world's spruces, is one of the most prominent forest trees in stands along the Pacific Northwest coast $[9,32,33]$. The native range of Sitka spruce is along the Pacific coast 
of North America from southern Alaska to northern California (Figure 1a). In coastal Alaska and British Columbia, Sitka spruce is a well-distributed tree species, but in Washington and Oregon it mostly occurs in a narrow strip along the coastal fog belt and extends inland for several kilometers along the major rivers [32,33]. Sitka spruce is restricted to an area of maritime climate with abundant moisture throughout the year. It is more tolerant of ocean spray than the associated trees species and often occupies positions on exposed headlands and beaches along the outer coast [32,34]. Sitka spruce, a prolific seed producer [35,36], can regenerate on a variety of seedbeds. It is commonly established on mixed mineral soil, e.g., exposed by disturbances such as landslides or logging; it also occurs in riparian zones [37-39].

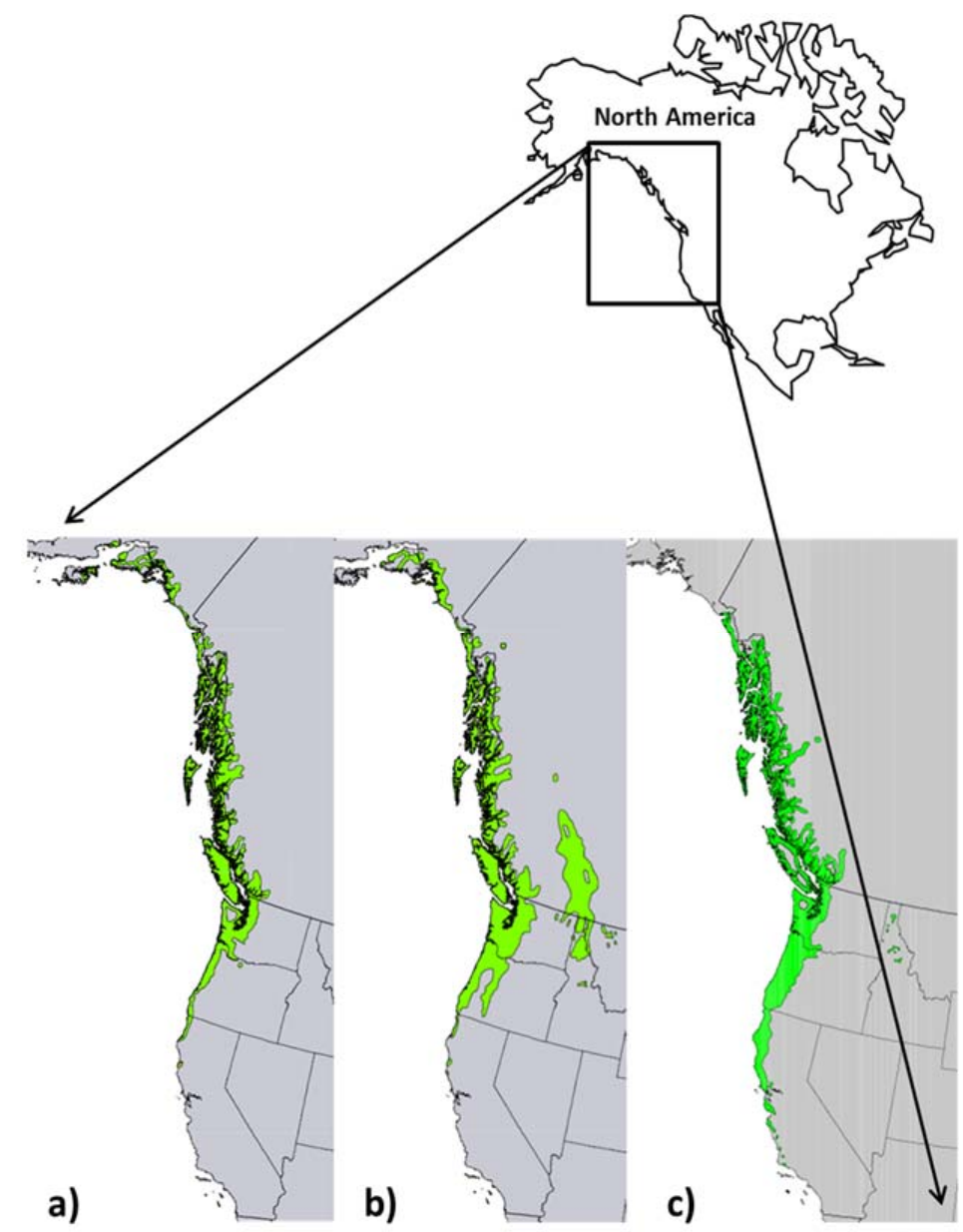

Figure 1. Native distribution of species for (a) Sitka spruce (Picea sitchensis (Bong.) Carr.); (b) western hemlock (Tsuga heterophylla (Raf.) Sarg.); and (c) red alder (Alnus rubra (Bong.)).

\subsection{Range and Habitat of Western Hemlock}

Western hemlock is the most common and dominant species along the Pacific coast of North America and it also abundant in the coastal and Cascade Mountains of the Pacific Northwest (Figure 1b). Along the Pacific coast, its range extends north from central California to the Kenai Peninsula in Alaska, approximately $3200 \mathrm{~km}$. It is a dominant forest species in British Columbia and Alaska along coastal mountains and on islands and its range extends into much of western Washington, Oregon and British Columbia. Western hemlock thrives in a mild, humid climate where frequent fog and precipitation occur during the growing season [33,40]. Western hemlock is a prolific seed producer $[35,36]$ and natural regeneration is often dense after logging [36-38,41]. Western hemlock is a very shade tolerant species [42] and regenerates abundantly as an understory tree and in organic soils and on woody 
debris and logs [43-46]. In coastal British Columbia and Alaska, it is co-dominant with Sitka spruce and commonly forms mixed stands with spruce throughout much of this range $[9,37,38]$.

\subsection{Range and Habitat of Red Alder}

The range of red alder, extends from southern California to Yakutat in coastal Alaska (Figure 1c) [47]. Its range occupies much of the same region as for western hemlock and Sitka spruce although it does not extend as far north as its conifer associates. Red alder is common in riparian areas, along roadsides and avalanche slopes, on stream bottoms with rocky, moist soils, and along beaches where creeks enter seas [48-51]. It is frequently present in a linear arrangement on the landscape as a response to some of these disturbances. As a pioneer species, red alder is common on exposed mineral soil and requires higher light levels than its associated tree species, thus is classed as intolerant of shade [42]. Its ability to fix atmospheric nitrogen permits establishment on geologically young or disturbed sites with low levels of soil nitrogen. Red alder is an aggressive colonizer on avalanche paths, roadsides, log landings, skid trails and other areas where mineral soil has been freshly exposed to seedfall [37,52].

\section{Silvics and Species Growth of Natural Stands}

\subsection{Silvics of Spruce and Hemlock}

Sitka spruce, is a valuable commercial timber species for lumber, pulp, and various specialty products. High strength-to-weight ratio and resonant qualities of clear lumber are attributes that have traditionally made Sitka spruce wood valuable for specialty uses, such as sounding boards for high-quality pianos; guitar faces; ladders; construction components of experimental light aircraft; oars, planking, masts, and spars for boats [32,53]. Sitka spruce trees often attain great size. In Alaska, mature trees near sea level often exceed $61 \mathrm{~m}$ in height and $3 \mathrm{~m}$ in diameter [54,55]. Stands with Sitka spruce as a major component tend to be dense, with high yields and large tree size [32,56-59].

Sitka spruce typically grows in mixed stands and is commonly associated with western hemlock throughout most of its range. Pure stands usually occur in early successional stages and as tidewater stands; Sitka spruce is often the dominant conifer in riparian forests near rivers and streams [9,32]. The most extensive pure stands are found on the Kodiak-Afognak Archipelago, in Alaska, at the extreme west extension of the range where it is the only conifer present on this group of islands [32,60]. Sitka spruce may live to 700 or 800 years [58]. This species has been described as being in the tolerant and intermediate shade-tolerant classes and is more shade tolerant than most conifer associates such as Douglas-fir (Pseudotsuga menziesii (Mirb.) Franco) but less tolerant than western hemlock [42].

Western hemlock is a large conifer tree growing to $50-70 \mathrm{~m}$ tall, with a diameter of up to $2.7 \mathrm{~m}$ [40]. Western hemlock is an important tree in the Pacific Northwest for timber and paper production [33,40]. Common uses include plywood framing, boxes, pallets, crates, and other construction purposes [53]. It is the largest species of hemlock species and is a very shade-tolerant tree that is matched or exceeded in shade tolerance in the region only by Pacific silver fir [42]. The tallest known hemlock found in California, was $82.83 \mathrm{~m}$ tall. Western hemlock typically does not live more than 500 years [58].

Western hemlock may form pure stands or be a component of mixed stands commonly with Sitka spruce along the coastal region of North America [32,37,61]. Natural stands of western hemlock along the Pacific coast attain appreciably higher yields than Douglas-fir stands having the same site index with the weighted mean annual increment of western hemlock 33 to 101 percent more than the mean annual increment for Douglas-fir [62,63]. On the Olympic Peninsula, western hemlock out-produces Douglas-fir by 25-40 percent and similar relationships occur in south coastal British Columbia [64]. The higher mean annual increment of western hemlock apparently is due to the ability of western hemlock stands to support greater density; individual trees also have higher volume and better form than other associated species [61]. 


\subsection{Silvics of Red}

Red alder is the most common broadleaf tree in the Pacific Northwest and is the only commercial tree species west of the Rocky Mountains with the capacity to fix atmospheric nitrogen [65]. Its ability to fix atmospheric nitrogen permits establishment on geologically young or disturbed sites with low levels of soil nitrogen [66]. Red alder is an important species for the hardwood industry in the Pacific Northwest [65,67] due to its excellent gluing, staining, and finishing properties. Its common uses include plywood, furniture, veneer, cabinetry, millwork, and pallets [53].

Red alder grows in both pure and mixed stands, with pure stands typically confined to stream bottoms and lower slopes [52]. It is more common in mixed stands and occurs as a minor component in most North Pacific forest cover types [68].

Red alder is a relatively short-lived species, requires more light than its associated tree species, and is classed as intolerant of shade [42]. It is a pioneer species, and requires high light levels to germinate and become established $[65,66]$. In Washington, Oregon, and British Columbia, mortality of red alder increases rapidly in stands over 90 years old, and few alder remains by the age of 130 years [69].

\subsection{Eight and Stand Growth of Spruce, Hemlock and Alder}

Height growth for Sitka spruce is relatively slow for the first few years but increases rapidly thereafter. On average productive sites in southeast Alaska, Sitka spruce trees can be expected to reach about $27 \mathrm{~m}$ in height within 50 years after attaining breast height $[55,70]$. Average site index at elevations near sea level varies inversely with latitude, declining from $48 \mathrm{~m}$ at base age 100 years in Lincoln County, OR, to $33 \mathrm{~m}$ in southeast Alaska, at the rate of about $1 \mathrm{~m}$ per degree of latitude [62]. Height growth of Sitka spruce and western hemlock are nearly equal during the period of most rapid growth, but spruce grows more rapidly in diameter. Observations within the natural range of spruce show that growth rate also declines with increasing elevation. Sitka spruce continues to maintain height growth longer than hemlock and also lives longer [58].

Mixed stands of western hemlock and Sitka spruce are especially productive in the coastal zone of Oregon and Washington, where the mean annual increment of such stands frequently exceeds $42 \mathrm{~m}^{3} /$ ha [40]. At higher elevations and farther north, mixed stands of western hemlock are also highly productive and the Pacific Northwest coast climate is excellent for tree growth with mild winters and abundant moisture and a lack of fire [37,61]. Hundred-year site index was about 49-61 m, the net periodic increment was 11-20 $\mathrm{m}^{3} / \mathrm{ha}$ [54] and decreases north with latitude [62]. A 26-year-old western hemlock in a northwestern Washington stand reported total biomass of 231 metric tons/ha [63].

On favorable growing sites, red alder trees can eventually reach 30 to 40 meters tall and 55 to 75 centimeters in diameter. Red alder exhibits rapid early height growth and then growth slows considerably after age 15-20 years (Figure 2). Height growth of small trees is exceptionally rapid and on favorable sites trees can grow $1 \mathrm{~m}$ or more the first year, and on all but the poorest sites, trees surpass breast height $(1.3 \mathrm{~m})$ by the second year [47]. Maximum annual height growth of more than $3 \mathrm{~m}$ per year can be achieved by 2- to 5 -year-old trees. On good sites, trees may be $9 \mathrm{~m}$ at age 5 years, $16 \mathrm{~m}$ at age 10 years and $24 \mathrm{~m}$ at age 20 years [47,71]. Height growth rate decreases substantially beyond age 20. Dominant tree heights range from 10 to $25 \mathrm{~m}$ at age 20 years and at age 50 years range from 18 to $37 \mathrm{~m}$ [72]. By age 15, red alder has reached more than half of its total height and height growth attains nearly all of its mature height before age 40 years [69]. 


\section{Height Growth Comparison}

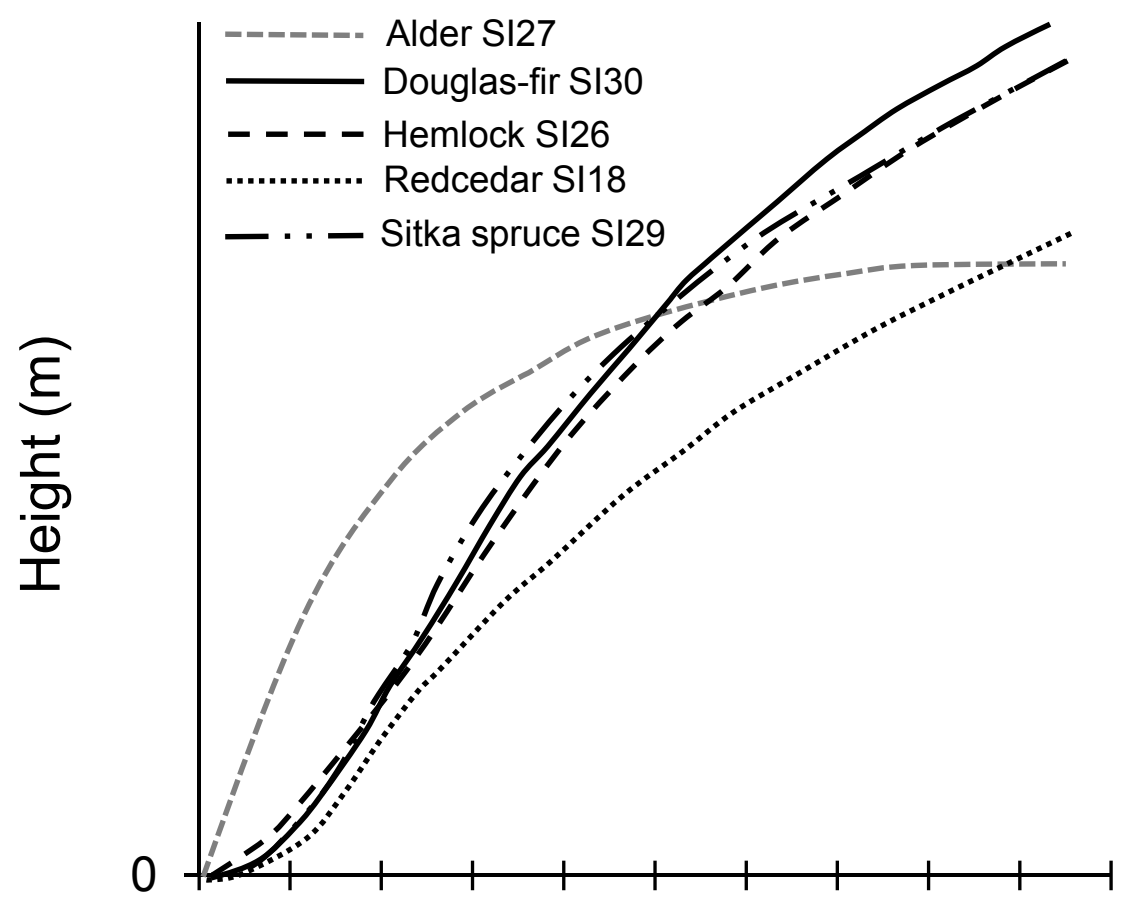

Age (year from seed)

Figure 2. Comparison of height growth for red alder and associated conifers to age 100 years. Height growth is for stands of predominantly pure species (figure modified from Green and Klinka [73]).

Young red alder height growth is more rapid and has significantly greater early height growth than any of the common conifer associates. On average sites, Sitka spruce height is only $1 \mathrm{~m}$ at age 5 years, $2 \mathrm{~m}$ at age 10 years and $4 \mathrm{~m}$ at age 15 years compared with $5 \mathrm{~m}$ at age 5 years, $11 \mathrm{~m}$ at age 10 years and $15 \mathrm{~m}$ at age 15 years for red alder (Figure 2). Green and Klinka [73] report that early height growth is slightly higher for western hemlock followed by Douglas-fir and Sitka spruce, with the slowest height growth for western redcedar (Thuja plicata Donn ex D. Don). However, differences in early height growth are small among the four most common conifer associates with each species lagging behind red alder [73,74]. Longer-term height growth and stand development shows very different height growth patterns for alder and conifers. As previously reported, alder height growth rapidly declines after age 20 years whereas height growth increases and is sustained for Douglas-fir, hemlock and spruce $[75,76]$. On average sites, Sitka spruce and western hemlock all surpass red alder at about age 50 [73]. Western redcedar height growth is somewhat slower and may take as long as 80 years to achieve the same height as red alder [73]. It is worth noting that these projections are for pure stands and not for mixed alder-conifer stands where tree species interact.

Most available information on red alder growth and yield comes from natural unmanaged stands and stand growth is significantly affected by initial stand density, site factors such as soil, moisture and nutrients and management regimes including thinning and vegetation control $[65,77]$. Stand maximum cubic volume (about $500 \mathrm{~m}^{3} /$ hectare) is attained at age 50 to 70 years [72,78-80]. Density appears to have an important effect on stand growth with most rapid growth in stands of moderate to moderately high densities [81-83]. An average tree diameter of $38 \mathrm{~cm}$ can be reached after 25 to 30 years on good sites with stand volumes of $275 \mathrm{~m}^{3} /$ hectare [84]). The site index and height growth 
equations developed from natural stands [71] may underestimate potential height and volume growth of plantations at moderate to moderately high densities [85].

Alder must remain in the upper canopy to survive in mixed stands. Red alder is shade intolerant and highly susceptible to suppression. When slower growing but longer lived conifers eventually overtop alders, these alders can die, and alders are not reestablished without new disturbances $[69,86]$. Long-term succession for alder stands is not clearly understood and appears to depend on the establishment of conifer associates, shrub development, geographic location and specific site factors $[47,65]$. Reaction of alder to competition is influenced by many factors, including the size, species composition, and density of the competing vegetation in the upper canopy and in the understory. Stand density strongly influences survival and growth of alder. Alder's rapid early growth and high stem densities make it difficult for other shade-intolerant species to regenerate and grow if they do not become established at the same time alder invades a site. Douglas-fir can be eliminated in dense, young alder stands while more shade-tolerant species such as western hemlock, Sitka spruce and western redcedar can survive, grow into the canopy, and ultimately dominate the site (Figure 2) [52].

\section{Mixed Red Alder-Conifer Stands}

Mixed red alder and conifer stands commonly occur throughout the coastal Pacific Northwest and Alaska wherever alder naturally occurs, and red alder is a common associate with western hemlock, Sitka spruce, Douglas-fir and other conifer species. However, establishment, species composition and growth vary considerably and depends on a number of site conditions including disturbance history, seed source, initial stand and tree density, competing vegetation and other factors. Mixed alder-conifer composition and growth have not been well documented and widely vary with tree species composition, disturbance history and management practices. The following section summarizes a set of research studies where composition, growth and stand development were carefully reconstructed for some watersheds in southeast Alaska. These studies provide a basis for stand development in mixed red alder conifer stands and we describe tree height growth, stand structure, understory plant development and aquatic and riparian habitats for mixed red alder-western hemlock/Sitka spruce stands in southeast Alaska.

\subsection{Mixed Red Alder-Western Hemlock/Sitka Spruce Stands in Southeast Alaska}

Research on mixed alder conifer stands in Alaska was intended to assess the influence of red alder on vegetation, invertebrates, wood, and fish. Most of these studies were established in two large watersheds on Prince of Wales Island, Alaska (Figure 3) following logging that led to a broad range of red alder and conifer mixtures (predominantly western hemlock, and Sitka spruce). Research focused on wood production (live and dead trees); understory vegetation; aquatic and riparian ecology across non-riparian, riparian, and associated headwater stream habitats. Many of these studies have been published as separate papers [39,51,87-92], but these results have not been synthesized to assess the role of red alder in these conifer dominated forest ecosystems. This research was supplemented by several smaller case studies throughout the region to broadly assess the role of red alder for improving biodiversity and other ecosystem services in the western hemlock-/Sitka spruce forest type of coastal Alaska. Data on forest stand structure were used to develop tree height growth and stand development patterns. Understory plant diversity and abundance and biomass data was used to assess terrestrial wildlife habitat, invertebrate data and coarse wood in streams was used to assess aquatic and riparian habitat. We integrated research findings and broadly assessed the influence of red alder on ecosystem linkages including the abundance and diversity of understory plants and the wildlife that these plant communities support, and the abundance and species richness of aquatic and terrestrial invertebrates and the bird and fish communities that feed on these prey. Lastly, we assess some of the compatibilities and potential tradeoffs of including red alder in conifer-dominated forest ecosystems in southeast 
Alaska and we broadly assess the role of broadleaf-conifer forests for improving biodiversity and other important ecosystem services in other forest ecosystems.

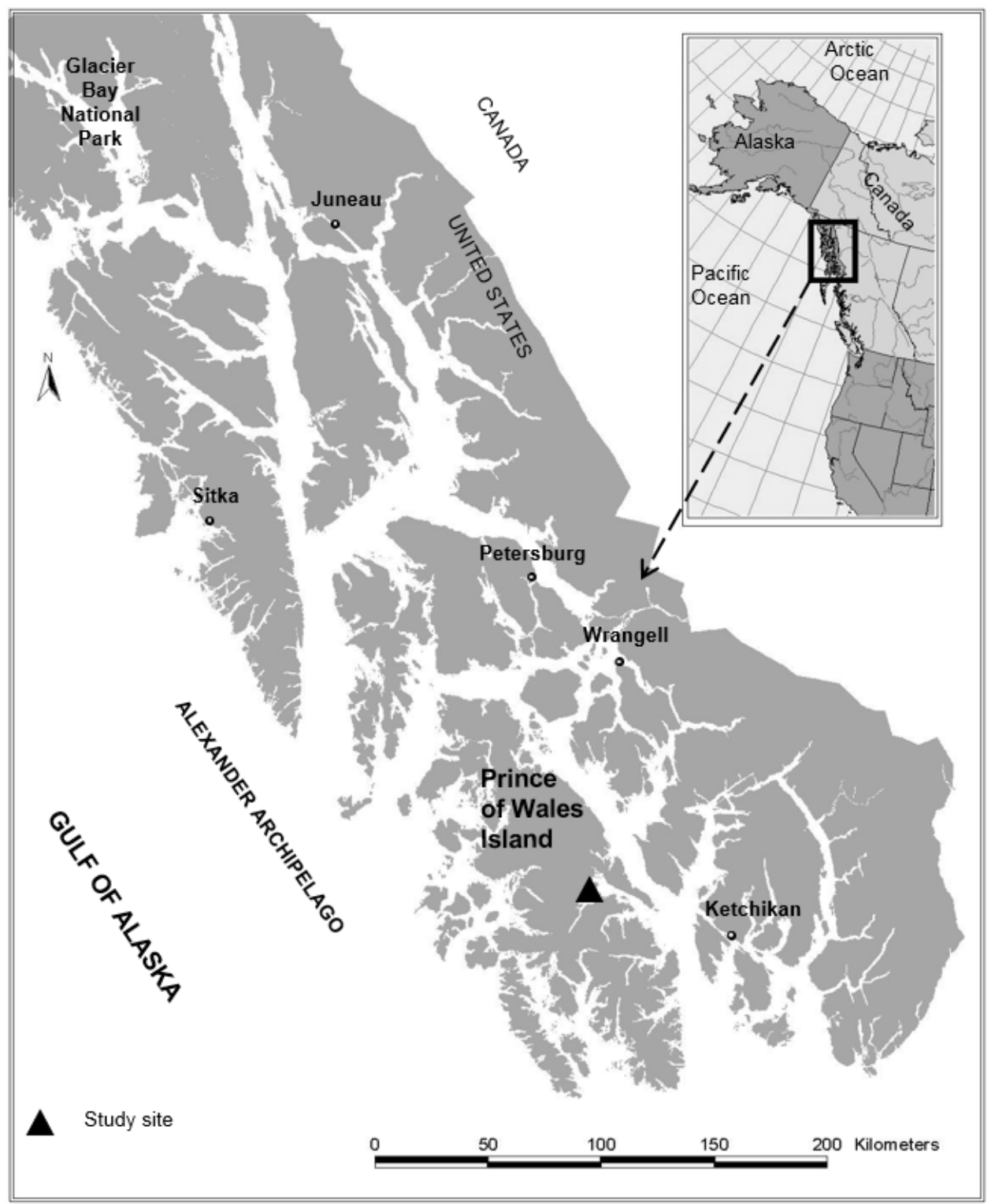

Figure 3. The research study area of southeast Alaska. The study area including mixed alder-conifer young-growth stands is indicated as a triangle.

\subsection{Tree Height Growth of Alder-Conifer Stands}

Tree height growth analysis revealed different growth patterns for alders and conifers in these mixed stands. Alders exhibited rapid early height growth for first 20+ years but then slowed. Initially, conifers grew more slowly for the first 20 years, but during the following 20-30 years they consistently had greater height growth than associated alders (Figure 4a). However, the height growth of alders and conifers varied considerably among sites. At an alder-dominated site (Alluvial Fan-AF, 64\% alder, Figure $4 \mathrm{~b}$ ), the alders at the age of 10,20 and 30 years averaged $+4.0,+1.5$, and $-2.0 \mathrm{~m}$ taller in height compared with conifers of the same age [88]. Height of dominant conifers were equal to the tallest alders at about 25 years after cutting (Figure $4 \mathrm{~b}$ ), and in the stand at age 45 years, conifers averaged about $4.6 \mathrm{~m}$ taller than the associated alders. At the AF site, height growth of alders was uniform with all of the alder heights slightly greater than $24 \mathrm{~m}$ at age 45 years. In subsequent years, 
conifers continued to grow rapidly while the alders consistently slowed in height growth. At a conifer-dominated site (Lower Example-LE, 18\% alder, Figure 4c), this same general height growth pattern for alders was apparent with rapid early height growth followed by declining growth. The decline in height growth for alder at the LGE site, however, was more pronounced than at the AF site. Alders at this site at the age of 10,20 and 30 years averaged $+2.1,-0.5$, and $-4.6 \mathrm{~m}$ different in tree height compared with conifers of the same age. Height of dominant conifers were equal to the tallest alders at about 18 years after cutting (Figure 4c), and in the stand at about age 45, conifers are now $9 \mathrm{~m}$ taller than the associated alders. However, in all of these mixed stands, dominant spruce and hemlock emerged from dominant alders in the overstory in 18-25 years (Figure 4a) and much sooner than expected (stand age 50, Figure 2) based on height growth of pure red alder and conifer stands.

\section{All Sites}

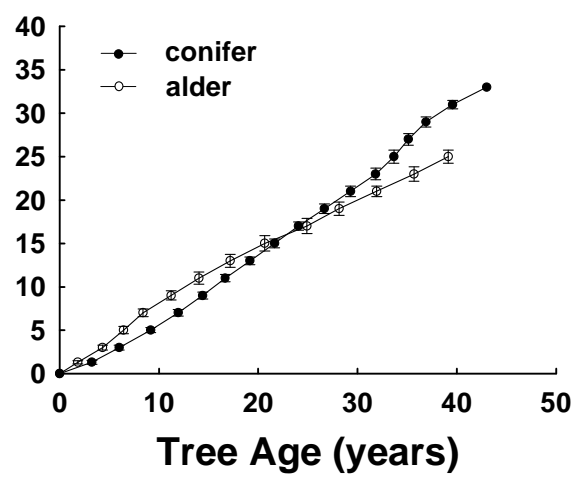

(a)

\section{Alluvial Fan}

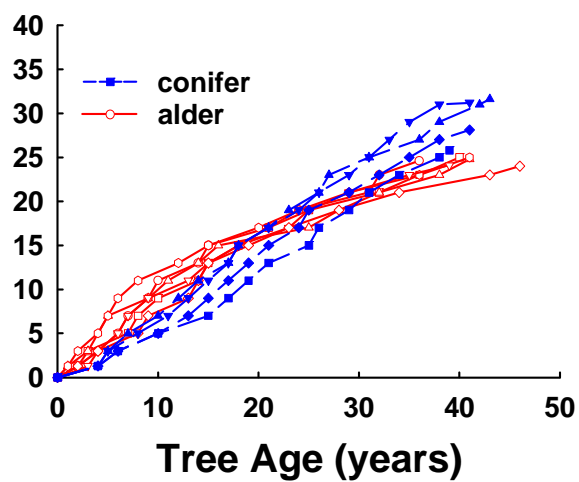

(b)

\section{Lower Example}

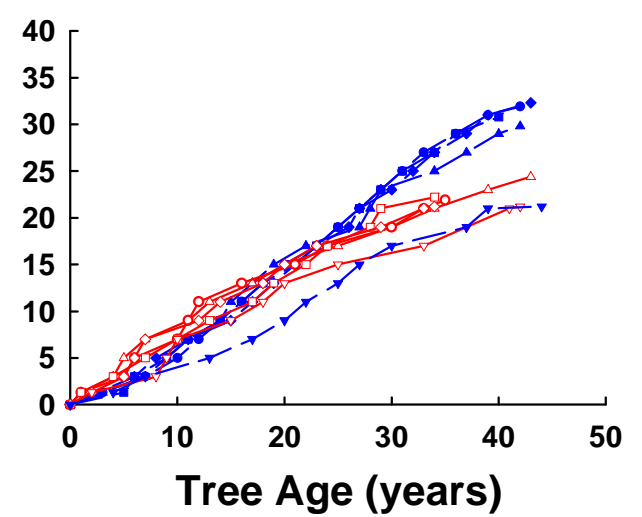

(c)

Figure 4. Height growth of dominant red alders and conifers (Sitka spruce and western hemlock) at study areas including (a) average of all sites; (b) average height growth for alders and conifers at an alder-dominated site ( $64 \%$ alder); and (c) alder and conifer trees for a conifer-dominated site (18\% alder).

Red alder tree height growth slows considerably by age 20-30 years and approaches maximum total height before age 50 years while both spruce and hemlock continue to rapidly increase in height and eventually overtop the surrounding alder. Longer-term stand development of these mixed alder-conifer forests have not been studied in Alaska. Red alder is expected to eventually die within a few decades of being overtopped and suppressed by surrounding conifers but it is unclear how long this will take. Red alder is a relatively short-lived species and other research in the Pacific Northwest suggests that the alder will succumb in $100-150$ years or less $[69,86,93]$. Red alder is expected to die 
out of these stands but it is unclear how long this will take. Some researchers in Pacific Northwest have reported that by 50 years most alder stands were breaking up and few stands remain intact beyond 100 years [85]. Newton and Cole [79] report for stands in Oregon that all alders will succumb in less than 130 yearsThe presence of alders may mitigate the intense stage of stem exclusion in pure conifer even-aged stands in Alaska $[38,94]$ and these mixed alder-conifer stands allows more light for development of understory plants. Also, when alders die out they may create more gaps in the canopy and lead to a condition that is either more open [69] or favors regeneration of new trees or shrubs. Thus, red alder may have a legacy in these forests even long after it has died and decayed.

\subsection{Stand Structure of Alder-Conifer Stands}

Diameter distributions of trees differed between conifers and alders for these 45-year-old mixed alder-conifer stands in Alaska. Conifers had many more trees in the smallest size classes with decreasing numbers of trees in progressively larger sizes following a reverse J-shaped diameter distribution. These conifers were all of the same age and the stratified diameter distribution is a common stand development pattern for even-aged conifer stands in the region [38,57]. In contrast to the conifers, the diameter distribution of alders had a bell-shaped distribution with the most alders in the 20-30 cm diameter classes, and fewer smaller and larger diameter trees (see Figure 3 in [88]). Stands with increasing proportions of alder had fewer small diameter trees but more mid-sized diameter alders and a few large diameter conifers. The alder in these stands provided a different tree size cohort than the conifer-dominated stands that contained numerous small diameter trees. Alders were evenly distributed with most trees in a narrow diameter $(20-30 \mathrm{~cm})$ and overstory height $(20-25 \mathrm{~m})$ range. In contrast, all conifers were unevenly distributed with a few taller and larger-diameter trees and numerous smaller-diameter trees. These mixed alder-conifer stands created a multi-layered forest canopy with a few dominant overstory conifers, a mid-canopy level of red alder and a lower canopy level of small diameter conifers.

Tree species composition was related to differences in stand basal area and density of trees. Alder composition among the nine stands showed a significant decrease in total stand basal area and wood production with increasing proportion of alder basal area [88]. Tree density however, was not closely associated with alder composition. While alder diameters were relatively similar among all of the sites, the average diameter of all conifers significantly decreased with increasing proportion of alder basal area. However, there was also no significant difference in mean diameter of the 100 largest trees $\cdot$ ha $^{-1}$ with increasing proportion of alder basal area in the stand and the largest diameter conifers appeared to be relatively independent of alder composition and large diameter trees [88]. These large diameter trees have important future ecological contributions, particularly for providing large woody debris (LWD) in streams and riparian habitats, and conifers often grow faster in the presence of alder [95] and because of improved soil fertility [96]. One of the major objectives of forest management in riparian zones is the production of large-diameter trees along streams because these trees provide an important source of LWD recruitment for stream structure [97,98]. These trees will provide potential woody debris for instream channels that is critical for maintaining stream stability, reducing sediments, and providing habitat for fish and other aquatic organisms [98].

Red alder is an important structural component of young-growth riparian stands. In riparian areas, tree density, basal area of live and dead trees, and mean diameter of live conifers were not significantly related to the percent of alder in the stand. Red alder was much more concentrated immediately along stream margins within $1 \mathrm{~m}$ distance from the stream bank [39]. A similar trend in alder spatial distribution was found in the coastal mountains of Oregon where this species was located closer to the streams versus farther away [99-101]. The presence of red alder did not inhibit the production of large-diameter conifers, and both alder and conifers provided small woody debris for streams in southeastern Alaska. The presence of red alder in riparian stands also did not influence the type or size of dead trees. Whether alder or conifer, nearly all dead trees in this study were small. Standing dead was the most frequent type of dead tree indicating that most trees are dying 
from suppression in these dense forests. Tree death in old-growth forests is markedly different, with dominant and codominate trees dying in a variety of ways to create canopy gaps [102]. This pattern of tree death in young stands was similar for both conifers and alders, and small dead alders and conifers were by far the most abundant on a stem density basis $[39,88]$.

\subsection{Understory Plant Diversity and Wildlife Habitat of Alder-Conifer Stands}

The understory plant species richness of these mixed alder-conifer stands is quite high, however, the most species rich stands were those stands with more even mixtures of alders and conifers and higher than either the conifer dominated or mostly alder stands [7]. Understory canopy coverage appeared to be closely related to the amount of alder in the stand, and understory plant cover increased with increasing proportion of alder basal area. Analysis of cover for vascular plants and non-vascular plants (bryophytes) showed different relationships. The non-vascular plant cover was similar for all of the sites and cover varied among sites from about 35\% to 45\%. There was no significant relationship between the cover of non-vascular plants and the proportion of alder basal area [7]. In contrast, the vascular plants showed a strong correlation between increasing vascular plant cover, biomass and increasing proportion of alder basal area [51].

Both shrub and herbaceous biomass increased significantly with increasing percentage red alder [51]. Total aboveground biomass of understory vegetation ranged from 10 to $616 \mathrm{~kg} / \mathrm{ha}$ across the nine stands and was highly correlated with proportion of red alder in the stand [7,51]. Very few tree seedlings were found on the plots. The significant increase in plant biomass during the summer had pronounced positive impacts on the available forage for Sitka black-tailed deer with carrying capacity for deer in summer increasing significantly (from 0.05 to 122.18 deer days per hectare) with increasing percentage red alder [51].

The greater diversity and abundance of vascular plants found with more alder improved habitat for small mammals [51]. There was no significant relationship between percent red alder and songbird diversity [90]. Although most songbird species did not vary with percent red alder, the abundance of the Pacific-slope flycatcher (Empidonax difficilis), an aerial insectivore, increased with percent of alder in forest stands, resulting in higher overall bird abundance [90]. Nesting density of all songbird species combined was also positively associated with percent red alder, and given that nesting success did not differ between stand types, total stand-level nesting success was presumably higher in the red alder stands. The importance of red alder to birds breeding in coniferous forests of the Pacific Northwest and southeastern Alaska is uncertain. Dense conifer stands appear to have low bird diversity [103] and abundance [104]; higher densities of live deciduous trees have been shown to support greater diversity and abundance of birds in young-growth forests [105-107]. The simple stand structure and sparse forest understory of dense young-growth conifer stands appear to limit the number of nest sites available to birds, and reduce the concealment of nests, a feature associated with successful nesting for some open-cup nesting species $[108,109]$. Deciduous vegetation in coniferous stands is important for successful nesting for some songbirds in Douglas-fir plantations in British Columbia [110]. Red alder may be an important foraging substrate [105,106], but this relationship has not been studied. Because insects from foliage are a primary food source for insectivorous birds [111,112] and insect biomass is greater in deciduous vegetation [113,114], it follows that birds may be more successful when foraging for insects in red alder trees. Therefore, mixed red alder-conifer stands potentially provide more food, more and safer nest sites, and reduced susceptibility to nest predation, for certain bird species.

\subsection{Aquatic and Riparian Habitat of Alder-Conifer Stands}

Streams with more red alder in their adjacent riparian zones transported significantly more invertebrates and organic detritus from headwaters to downstream, fish-bearing habitats than streams with predominantly conifer along their banks. Streams at the higher end of the red alder density continuum delivered about four times more invertebrate biomass than streams canopied predominantly with conifers [115]. Aquatic invertebrate mass comprised three-quarters of the fluvial 
export from headwaters to fish-bearing habitats, while terrestrial species comprised one-quarter of the export. Midges were the most abundant invertebrates in the stream transport, followed by baetis mayflies and nemourid stoneflies.

Riparian management that alters plant communities may change food resources within a stream and its surroundings [116]. Little is known about the influence of these developing riparian communities on headwater stream productivity and downstream fish. Red alder could have a variety of impacts on streams, such as changes in light penetration and allochthonous inputs. These effects could lead to changes in aquatic productivity and terrestrial invertebrate inputs to streams [117]. Some riparian tree species contribute more terrestrial invertebrate mass to streams than others [118] and red alder appears to support relatively high levels of prey for fish $[117,119,120]$. This is significant because over half of the prey biomass ingested by juvenile salmonids in southeastern Alaska is terrestrial and originates from adjacent riparian vegetation [117]. Riparian red alder and other vegetation types along streams can also have major influences on stream riparian soil nutrient levels. For example, red alder stands have increased soil nitrogen levels from a few years after harvest until the stand senesces and is replaced by conifers [121,122].

Habitats immediately adjacent to headwater streams may have a significant influence on foodwebs in fish-bearing reaches downstream. Over 70\% of streams within a drainage network are headwater streams [123], and are sources of sediment, water, nutrients, and organic matter for downstream habitats [124]. Transport of organic and inorganic material in headwater streams draining upland forests may affect physical and biological processes in downstream reaches. For instance, sediment produced in headwater systems moves through channel networks and alters channel morphology [123], creating various channel environments and modifying patterns of riparian structure and hyporheic exchange in downstream reaches $[125,126]$. Movement of detritus and invertebrates from headwaters to downstream food webs may alter productivity, population density, and community structure of stream biota in downstream reaches [127].

Some vegetation responses differed between riparian corridors and non-riparian stands. In riparian stands, red alder was highly clumped and was concentrated along stream margins. Tree density, basal area of live and dead trees, and mean diameter of live conifers were not significantly related to the proportion of red alder within riparian forests [39]. The number of large diameter conifers was similar in riparian stands across the full range of red alder-conifer mixtures. Mean diameter of dead conifers increased slightly with increasing proportion of red alder. Similar to non-riparian sites, most dead trees within riparian stands were small and had died standing. The number of red alder large woody debris pieces in streams increased with increasing proportion of red alder in the riparian stand [87]. However, woody debris and sediment supply appeared to be governed by other factors such as recruitment, past logging practices, transport capacity, and decomposition rates and much of the woody debris from the original old-growth forest still persisted in the stream channels and provided physical function in streams [87].

Red alder appeared to have no direct relationship with salmonid densities [92]. Dolly Varden char (Salvelinus malma Walbaum) and juvenile coho salmon (Oncorhynchus kisutch Walbaum) densities were related to stream habitat conditions: including gradient, pool abundance, and the amount of large wood. Dolly Varden char were found in all reaches of the streams and in all streams where fish were present, whereas juvenile coho salmon were found in some but not all streams, and were most abundant in the lower gradient reaches. The density of all species decreased as gradient increased. The relatively low densities of all fish species combined with the limited amount of habitat suggests that the amount and quality of habitat were the primary factors limiting salmonid populations in these streams. 


\section{Functional Role of Mixed Red Alder-Conifer Forests}

\subsection{Role of Red Alder in Young-Growth Forests}

The inclusion of red alder in young-growth forests of southeast Alaska increased both their structural complexity and significantly improved their understory plant diversity and abundance. Mixed red alder-conifer stands provided different tree size distributions and more complex forest structures than found in even-aged conifer stands that develop after stand replacing disturbances such as clearcutting. Pure conifer young-growth stands in this coastal region are typically very densely stocked with relatively uniform tree height and diameter distributions and simple species composition of mostly Sitka spruce and western hemlock trees [70]. The inclusion of alder trees within these predominantly conifer stands provide different tree size distributions and create a multi-layered forest canopy with a few large overstory conifers, a mid-canopy level of red alder trees and a lower canopy level of small diameter conifers. These multiple canopy layers may be the most important feature of mixed alder-conifer stands and may distinguish these stands from predominantly even aged conifer stands of the same age. The presence of alder also did not significantly reduce the size of the largest trees in the stands $[39,88]$. Along with producing timber, these larger trees could also provide an important future source of large wood for instream fish habitat [39,97]. Furthermore, attempts to reestablish understory herbs and shrubs through thinning young-growth conifer stands has led to predominantly hemlock and spruce regeneration with little new herbaceous colonization [41,46]. Previous studies in southeast Alaska have shown that altering the composition of young-growth conifer forests with the inclusion of red alder (Alnus rubra Bong.) may improve aquatic habitat, provide better food resources for deer and other wildlife and thereby offset some of the negative consequences of clearcutting $[39,50,87,128]$.

Stand development in these 40-50-year-old mixed alder-conifer forests is highly dynamic and the composition of the current forest overstory is different than it was at earlier stages. In sites in southeast Alaska, Sitka spruce height growth increased earlier and trees grew more rapidly than for commonly associated species such as Douglas-fir in Pacific Northwest forests. In Oregon, Newton et al. [129] reported that the initial growth of red alder was substantially better than for Douglas-fir, and on wet sites it would take 38-42 years for Douglas-fir to emerge from the alder overstory. In Washington, Miller and Murray [95] reported that emergence of Douglas-fir from alder overstory would take about 30 years and they suggested limiting alder density to about 50-100 trees $\cdot \mathrm{ha}^{-1}$. In mixed alder-conifer stands in southeast Alaska, the conifer height growth responded more quickly (particularly for Sitka spruce) and in some sites emerged from the alder overstory in as little as 18 years. The free-to-grow condition for spruce is important as it provides ability for trees to rapidly increase in size and provide large diameter trees for both wood production and LWD for aquatic habitat [39]. However, the patchy distribution of alder within stands is also important and can have a significant effect on individual tree growth and stand development. The distribution of alder is largely an artifact of disturbance history with alder established following logging, landslides or other disturbance events. In a retrospective study, it is difficult to separate local site conditions from the inherent clumpy distribution of alder establishment. The Alaska region of the United States Forest Service (USFS) has recently installed studies that include mixed alder-conifer plantations with controlled planting density and distribution of alder following harvesting. The results of this study are still are unknown but should provide some valuable information to assess the effect of alder distribution and growth in mixed alder-conifer stands [130].

Sitka spruce may be a good candidate species to be grown with mixtures of red alder. Western hemlock, western redcedar and Sitka spruce are all more shade tolerant than Douglas-fir [42] and both hemlock and spruce respond well to release [131]. Both red alder and Sitka spruce frequently regenerate and become established on mixed mineral soils [38]. Newton et al. [132] also report that spruce can survive and grow in mixed alder-conifer stands under competitive conditions lethal to western hemlock and eventually emerge as alder matures. Previous studies in Sitka spruce plantations in Britain and 
Ireland indicated that mixed tree species plantation forests can support higher biodiversity than similar monoculture forests $[25,26]$. Sitka spruce also attracts a wide array of macrofungal communities that provide a number of important ecosystem services in both native and non-native Sitka spruce forests $[9,133]$. Humphrey [6] provides a comprehensive review dealing with the possibility and consequences of creating older forests and mixed species stands in Sitka spruce plantations in Britain. Overall, he concluded that spruce plantations are an excellent candidate for such conversions, as they are widespread, somewhat lacking in biodiversity conservation abilities in their current condition, and as they develop old-growth conditions faster than many native tree species forests.

\subsection{Improved Ecosystem Resilience of Mixed Alder-Conifer Stands}

The complex stand structures of mixed alder-conifer stands in coastal Alaska could improve ecosystem resilience and have important management implications for forest wildlife resources. The principal problem following clearcut logging is that dense conifer regeneration is followed by rapid canopy closure resulting in an understory with few herbs, few shrubs and little forage for as long as 150 years after canopy closure $[94,134,135]$. The reduced number of small diameter conifers found in more evenly mixed alder-conifer stands [88] allows more light to reach the forest floor that could help maintain understory plants. Research in these mixed alder-conifer stands documented a correlation of increasing herbaceous biomass and understory plant cover with increasing percentage red alder throughout the range of stands studied [7,51]. This is important from both a biodiversity perspective and a forest management perspective, because it is the herb component that is most difficult to maintain through secondary succession of even-aged stands following clearcutting in southeast Alaska [20,134], including precommercial thinning [41,136]. Summer food value increased with increasing red alder because the quantity of both forbs and shrubs increased with increasing red alder, and the nutritional quality of forbs and shrubs is particularly high in summer [51,137]. However, in winter, many of these red alder-associated species are either senescent (forbs and ferns) or of very low nutritional quality $[137,138]$.

Although inclusion of alder will not mitigate all wildlife habitat problems such as winter habitat for deer use, it may provide more benefits than would thinning of even-aged conifer stands. Well-planned silvicultural systems that include a mixture of red alder-conifer compositions could provide trees for timber production and also improve other forest resources that are often compromised in pure conifer young-growth forests in the region. The effects of mixed red alder-conifer stands for other wildlife species may differ from those for deer. For example, red alder stands with similar understories as found in these studies provided year round habitat for Keen's mouse (Peromyscus keeni sitkensis Merriam) that was equal quality to that of both upland and riparian old-growth forests [51,139]. Wildlife consequences of mixed red alder-conifer stands, therefore, differ seasonally and for different wildlife species depending on the wildlife's habitat requirements.

These mixed red alder-conifer forests provided more varied stand structures and had significant effects on forest ecosystem resources. Mature forests have complex forest structures including a wide range of tree sizes, snags, logs, and multiple canopy layers [19]. A major reason for improved understory plant diversity and abundance in partially cut stands in coastal Alaska is the wider range of tree size in these stands, compared to the simpler even-aged forests that develop after clearcutting [9,131]. Mixed red alder-conifer stands also have a wide range of tree sizes and contain more open forest canopies than even-aged conifer forests, providing the complex and diverse forest structures important for wildlife. Red alder stands may leave a legacy in these forests long after they have died and decayed. Gaps created where one or more large red alders have died leave conifer stands more open [69]. These gaps may also develop a second canopy by invasion of new trees. Longer-term stand development is less certain but without additional soil disturbances and enlargement of openings, western hemlock or other conifers are more likely to colonize the opening than red alder. The resulting complex canopy and open forest structure may occur decades earlier than 
in pure conifer forests where tree death may not begin until stands are 150 years old. The longer-term benefit of red alder may be that its death accelerates the transition to a mature forest structure.

\subsection{Role of Red Alder in Aquatic and Riparian Ecosystems}

Riparian zones play a crucial role in the structure and function of terrestrial and aquatic habitats [140]. Maintaining or managing for the development of mixed red alder-conifer stands in riparian zones could positively impact biodiversity of terrestrial and aquatic ecosystems through enhanced invertebrate abundance and diversity, stand structure, and nutrient cycling. Gomi et al. [87] concluded that red alder within young-growth riparian forests benefited both wood production and biological recovery in harvested headwater stream channels. While conifer-derived LWD plays an important structural role in aquatic systems (pool formation, sediment capture, cover for fish), smaller alder-derived woody debris and leaf litter increased invertebrate densities and diversity important as instream or downstream sources of food for fish [89]. An alder component in previously harvested fishless headwater stands may offset negative effects of timber harvest (such as sedimentation and loss of coarse woody debris) on downstream, salmonid-bearing food webs [119]. They found that young-growth alder sites exported significantly greater count and biomass of macroinvertebrates (70\% were aquatic) than did young-growth conifer sites, translating up to four times more fish biomass in suitable downstream habitats [119]. Riparian forests with red alder included in the overstory, along with denser shrub understory may also increase abundance of terrestrial-derived invertebrates that are important prey for juvenile salmonid and other predators [117]. Similarly, headwater streams with a greater component of alder in riparian zones exported significantly more detritus than streams with less alder $[115,119]$. This particulate organic matter is the driving energy source for ecosystem functioning in low-order streams [120]. In addition, greater benthic invertebrate diversity can be found in upland headwater streams if woody debris source and a red alder component are maintained in regenerating riparian forests following clearcutting [141].

Red alders apparently serve important biological functions in riparian forest ecosystems by providing nitrogen, high quality organic matter for decomposers and invertebrates, and better light penetration through the forest canopy than pure conifer stands $[65,107]$. In studies in southeast Alaska, more invertebrates were documented in streams with more riparian red alder, and red alder stems and leaf litter supported greater invertebrate species richness than conifers [115,117,119]. The smaller wood pieces_typically red alder-provided more habitat for invertebrates than larger pieces because of their higher surface-to-volume ratios. Management that balances the biological benefits of red alder with the physical benefits of larger conifers in young, successional forests should offer the most benefits—both biological and physical—-to stream and forest ecosystems.

\subsection{Compatibility and Potential Tradeoffs for the Inclusion of Alder in Conifer Forests}

Results suggest that red alder has important ecological functions in temperate rainforests of southeast Alaska. Although there are both benefits and tradeoffs for mixed red alder-conifer stands, the benefits of including red alder in predominantly young-growth conifer forests seem to outweigh the negatives. We measured and assessed a number of various resources of including alder along a compositional gradient from pure conifer to alder-dominated stands to help understand potential tradeoffs in management scenarios (Figure 5). Several biological resources were positively associated with increasing alder abundance (e.g., vascular plant cover, aquatic and terrestrial invertebrates, and songbird abundance), but live tree basal area steadily decreased along this gradient. Where conifer timber production is an exclusive resource objective, then inclusion of alder might be discouraged. However, red alder is also an important timber species in the Pacific Northwest region $[65,67,142]$, so the timber tradeoff of including red alder may be less than assumed. Mixed alder-conifer stands showed a correlation of increasing herbaceous biomass and understory plant cover with increasing percentage of alder [7,51] and a significant improvement of wildlife habitat with increasing alder [51]. Understory herbaceous cover significantly increased with increasing proportion of alder but wood 
production did not substantially decrease until red alder composition was greater than $40-50 \%$ (Figure 6). More evenly mixed proportions conifer-alder compositions appears to include relatively high levels of all resources that we measured. Thus, a balanced composition of conifers and red alder may maximize the broad range of ecosystem functions in these young-growth forests.

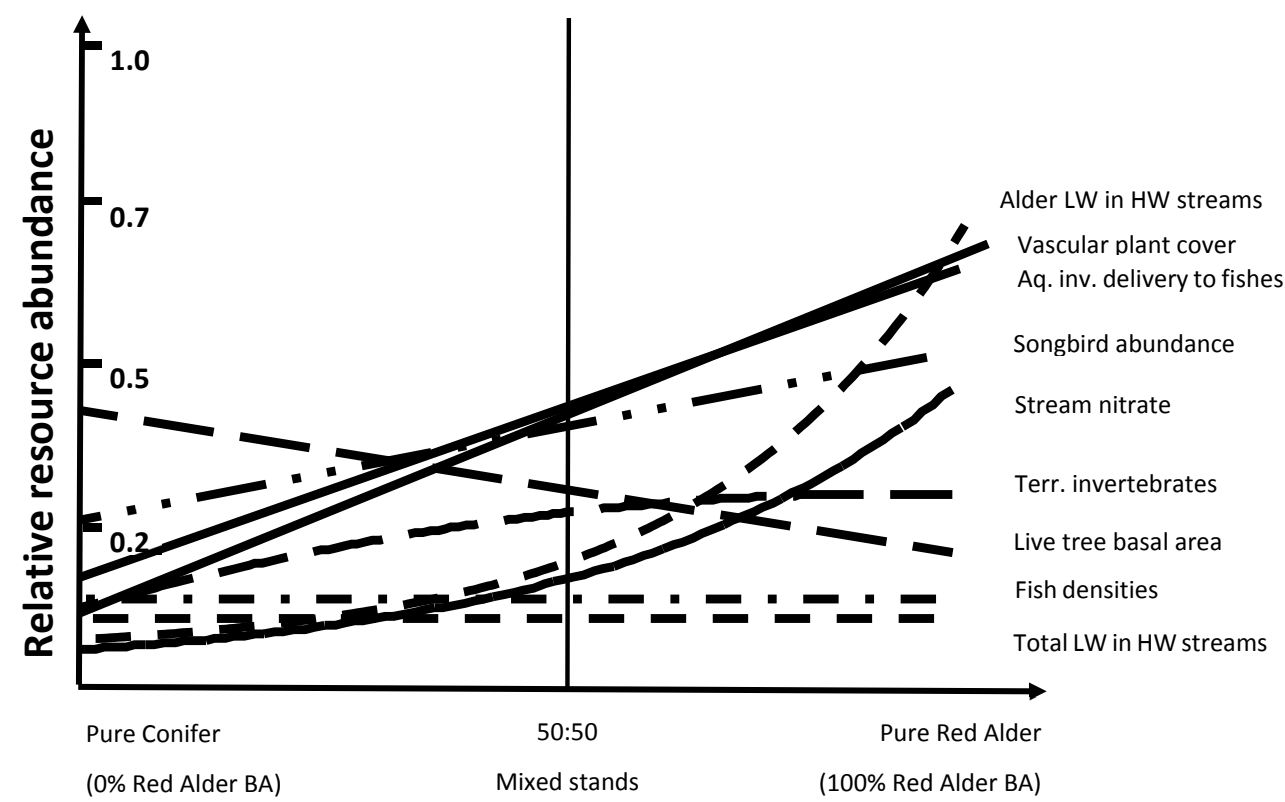

Proportion of Red Alder

Figure 5. Conceptual model of ecosystem services tradeoffs in young-growth stands with proportion of alder in mixed red alder-conifer stands in southeast Alaska. Legend abbreviations: LV, large wood; HW, headwater; Aq. Inv., aquatic invertebrates; Terr., terrestrial. Responses start from the $y$-axis at approximate position in unharvested systems and progress along the $\mathrm{x}$-axis as a proportion of red alder gradient.

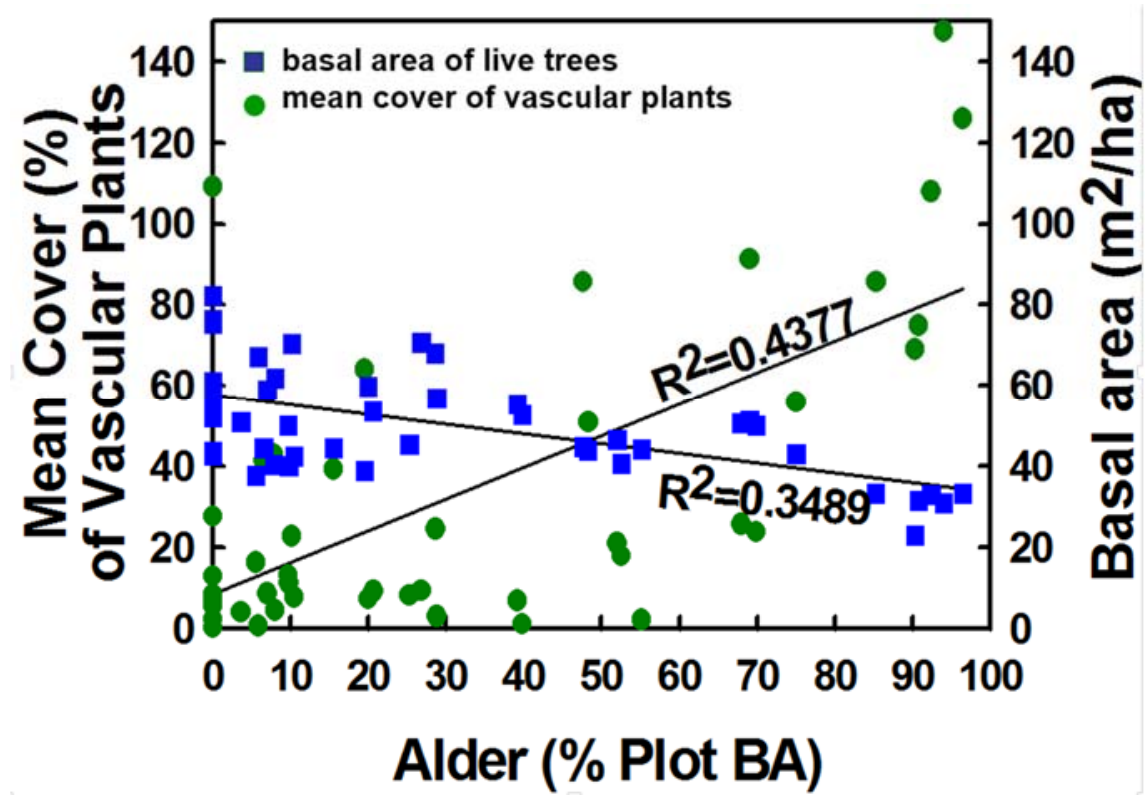

Figure 6. Mean basal area of live trees (combined red alder, western hemlock and Sitka spruce) and mean cover of vascular plants across an $\mathrm{x}$-axis gradient of the proportion of red alder basal area for all plots in the study areas. 
Red alder increased the abundance of food in aquatic habitats in its immediate vicinity and in downstream reaches. Within red alder stands, vegetation for both invertebrate and vertebrate herbivores was increased by the presence of red alder, an observation consistent with previous work in southeast Alaska $[117,119,139,143,144]$. Increased invertebrate prey availability likely affects many more species, such as bats and other small mammals, birds, and other wildlife in these young forested ecosystems. Also noteworthy was the trophic influence that upland red alder had on more distant habitats. Fish habitats downstream of red alder-dominated reaches were supplied with invertebrates (food for fish) and organic detritus (food for invertebrates) from upstream headwaters [119,127]. Also, aquatic food webs downstream of red alder received more prey and detritus than those below conifer dominated reaches [115].

There are many potential benefits in the altered stand structure of mixed alder-confer stands to offset the decline in total stand basal area and wood production with increasing proportions of alder. First, in riparian zones, a favorable long-term condition is the widely spaced distribution of very large conifers, usually Sitka spruce. Riparian zones experience repeated disturbance leading to the establishment and growth of alders along with conifers. The trajectory of recovery in these mixed stands leads to fewer, but larger conifers interspersed with alder. The alder holds the spacing for the conifers leading to a stand differentiation that promotes favorable future stand structure. While this structure leads to overall lower wood production, the distribution of the woody volume is positioned well to create future sources of large woody debris. The presence of red alder did not inhibit the production of large-diameter conifers, an important source of LWD for streams, and both alder and conifers provided small woody debris for fishless headwater streams in southeastern Alaska [39]. Additionally, Beechie et al. [145] found in LWD-recruitment and pool-formation models for NW Washington streams, that the time necessary for red alder to attain first recruitment of pool-forming LWD is 50\% shorter than for Douglas-fir, although alder LWD declines rapidly after 70 years due to species' short life span.

Although these results are from research conducted in the temperate rainforests of southeast Alaska, they have much broader geographic and ecologic implications and findings corroborates other research on red alder $[117,139,144,146-148]$. Red alder is widely distributed throughout the west coast of North America [47], and other species of alder occur throughout the world [149]. These alder species undoubtedly have biological properties similar to red alder in southeastern Alaska, and presumably have similar ecological effects in other ecoregions and ecosystems where they persist. Developing or maintaining alder beyond the young regenerating forested ecosystems as demonstrated here will likely affect associated plant and animal species, populations and communities, and ecosystem structure and function. Previous studies in Britain and Ireland indicated that mixed tree species plantation forests can support higher biodiversity and greater structural diversity than simple single-species forests [25-27,30,150]. Humphrey [6] provides a comprehensive review dealing with the possibility and consequences of creating older forests and mixed species stands in Sitka spruce plantations in Britain, and he concluded that spruce plantations are an excellent candidate for such conversions and they develop old-growth conditions faster than many native tree species forests.

\section{Summary}

There is increasing interest worldwide in the stand dynamics of mixed hardwood-conifer forests and their effects on forest productivity, biodiversity, wildlife, and other forest resources [149,150]. Our studies suggest that mixed red alder-conifer forests of southeast Alaska can provide more complex forest structures than pure conifer stands with more even diameter distributions and multiple forest canopy layers. Many ecosystem responses showed positive relationships with increasing proportions of red alder. Rather than viewing red alder as an undesirable, early-successional tree and managing it accordingly, there may be instances where managers can manipulate sites or existing vegetation to favor the establishment or maintenance of red alder. Altering the composition of young-growth forests to encourage a component of red alder may help improve habitat and food resources for deer, 
songbirds, and fish; thereby offsetting some of the negative consequences and main criticisms of timber harvesting, particularly clearcutting. Mixed species stands might not produce the same diverse benefits when the species share many silvicultural traits (e.g., Sitka spruce and western hemlock) compared to the addition of a broadleaf, deciduous species such as red alder. The decidedly different life histories, growth strategies, tree forms, and nutrient cycling between red alder and conifers appear to trigger richer physical and biological conditions when these trees grow together. Although our findings are from research conducted in the temperate rainforests of southeast Alaska, they may have broader geographic implications. Red alder is widely distributed throughout the west coast of North America [47] and other species of alder occur throughout the world. These alder species have biological properties similar to red alder in southeast Alaska and presumably similar effects in other ecoregions. Development of mixed hardwood-conifer stands beyond the young regenerating forest as demonstrated here will likely affect associated plant and animal species and ecosystem structure and function. This synthesis of studies on mixed red alder-conifer stands in Alaska has implications for managing multi-species stands in other regions to improve a number of natural resources and ecosystem services that are often lacking in single species plantations.

Acknowledgments: We acknowledge funding from the Wood Compatibility Initiative (WCI), USDA Forest Service, Pacific Northwest Research Station, Portland, OR, USA

Conflicts of Interest: The authors declare no conflict of interest.

\section{References}

1. Daily, G.C. Nature's Services; Island Press: Washington, DC, USA, 1997; p. 392.

2. Costanza, R.; d'Arge, R.; De Groot, R.; Farber, S.; Grasso, M.; Hannon, B.; Limburg, K.; Naeem, S.; O'Neill, R.V.; Paruelo, J.; et al. The value of the world's ecosystem services and natural capital. Nature 1997, 387, 253-260. [CrossRef]

3. MEA (Millenium Ecosystem Assessment). Ecosystems and Human Well-being: Synthesis; Island Press: Washington, DC, USA, 2005; p. 155.

4. Franklin, J.F. Toward a new forestry. Am. For. 1989, 95, 37-44.

5. Larsen, J.B. Ecological stability of forests and sustainable silviculture. For. Ecol. Manag. 1995, 73, 85-96. [CrossRef]

6. Humphrey, J.W. Benefits to biodiversity from developing old-growth conditions in British upland spruce plantations: A review and recommendations. Forestry 2005, 78, 33-53. [CrossRef]

7. Deal, R.L. Management strategies to increase stand structural diversity and enhance biodiversity in coastal rainforests of Alaska. Biol. Conserv. 2007, 137, 520-532. [CrossRef]

8. Notaro, S.; Paletto, A.; Raffaelli, R. The economic valuation of non-productive forest functions as an instrument towards integrated forest management. The multifunctional role of forests-Policies, methods and case studies. EFI Proc. 2008, 55, 55-380.

9. Deal, R.L.; Hennon, P.; O'Hanlon, R.; D'Amore, D. Lessons from native spruce forests in Alaska: Managing Sitka spruce plantations worldwide to benefit biodiversity and ecosystem services. Forestry 2014, 87, 193-208. [CrossRef]

10. Grilli, G.; Jonkisz, J.; Ciolli, M.; Lesinski, J. Mixed forests and ecosystem services: Investigating stakeholders' perceptions in a case study in the Polish Carpathians. For. Policy Econ. 2016, 66, 11-17. [CrossRef]

11. Davis, L.S.; Johnson, K.N. Forest Management, 3rd ed.; McGraw-Hill Inc.: New York, NY, USA, 1987; p. 790.

12. Fox, T.R.; Jokela, E.J.; Allen, H.L. The development of pine plantation silviculture in the southern United States. J. For. 2007, 105, 337-347.

13. Evans, J.; Turnbull, J. Plantation Forestry in the Tropics, 3rd ed.; Oxford University Press: Oxford, UK, 2004; p. 480.

14. Huffaker, C.B. (Ed.) Theory and Practice of Biological Control; Academic Press Inc.: New York, NY, USA, 2012; p. 810.

15. Boyer, W.D. Pinus palustris Mill. Longleaf pine. In Silvics of North America; USDA Forest Service: Washington, DC, USA, 1990; pp. 405-412. 
16. McLaren, J.P.; Grace, J.C.; Kimberley, M.O.; Knowles, R.L.; West, G.G. Height growth of Pinus radiata as affected by stocking. N. Z. J. For. Sci. 1995, 25, 73-90.

17. Kimberley, M.; West, G.; Dean, M.; Knowles, L. The 300 Index-A volume productivity index for radiate pine. N. Z. J. For. Sci. 2005, 30, 13-18.

18. Salas, C.; Donoso, P.J.; Vargas, R.; Arriagada, C.A.; Pedraza, R.; Cesar, A.; Soto, D.P. The Forest Sector in Chile: An Overview and Current Challenges. J. For. 2016, 114. [CrossRef]

19. Franklin, J.F.; Cromack, K.J.; Denison, W.; McKee, A.; Maser, C.; Sedell, J.; Swanson, F.; Juday, G. Ecological Characteristics of Old-Growth Douglas-Fir Forests; USDA Forest Service: Portland, OR, USA, 1981; p. 48.

20. Hanley, T.A. Balancing economic development, biological conservation, and human culture: The Sitka black-tailed deer (Odocoileus hemionus sitkensis) as an ecological indicator. Biol. Conserv. 1993, 66, 61-67. [CrossRef]

21. Gamfeldt, L.; Snall, T.; Bagchi, R.; Jonsson, M.; Gustafsson, L.; Kjellander, P.; Ruiz-Jaen, M.C.; Froberg, M.; Stendahl, J.; Philipson, C.D.; et al. Higher levels of multiple ecosystem services are found in forests with more tree species. Nat. Commun. 2013, 4, 1340. [CrossRef] [PubMed]

22. Piotto, D. A meta-analysis comparing tree growth in monocultures and mixed plantations. For. Ecol. Manag. 2008, 255, 781-786. [CrossRef]

23. Cardinale, B.J.; Duffy, J.E.; Gonzalez, A.; Hooper, D.U.; Perrings, C.; Venail, P.; Narwani, A.; Mace, G.M.; Tilman, D.; Wardle, D.A.; et al. Biodiversity loss and its impact on humanity. Nature 2012, 486, 59-67. [CrossRef] [PubMed]

24. Kelty, M.J. The role of species mixtures in plantation forestry. For. Ecol. Manag. 2006, 233, 195-204. [CrossRef]

25. Humphrey, J.W.; Ferris, R.; Quine, C. Biodiversity in Britain's Planted Forests; Forestry Commission: Edinburgh, UK, 2003; p. 126.

26. Iremonger, S.; O’Halloran, J.; Kelly, D.L.; Wilson, M.W.; Smith, G.F.; Gittings, T.; Giller, P.S.; Mitchell, F.J.G.; Oxbrough, A.; Coote, L.; et al. Biodiversity in Irish Plantation Forests; Environmental Protection Agency: Wexford, Ireland, 2007; p. 69.

27. Felton, A.; Lindbladh, M.; Brunet, J.; Fritz, Ö. Replacing coniferous monocultures with mixed-species production stands: An assessment of the potential benefits for forest biodiversity in northern Europe. For. Ecol. Manag. 2010, 260, 939-947. [CrossRef]

28. Rothe, A.; Binkley, D. Nutritional interactions in mixed species forests: A synthesis. Can. J. For. Res. 2001, 31, 1855-1870. [CrossRef]

29. Berger, T.W.; Inselsbacher, E.; Mutsch, F.; Pfeffer, M. Nutrient cycling and soil leaching in eighteen pure and mixed stands of beech (Fagus sylvatica) and spruce (Picea abies). For. Ecol. Manag. 2009, 258, 2578-2592. [CrossRef]

30. Pretzsch, H.; Block, J.; Dieler, J.; Dong, P.H.; Kohnle, U.; Nagel, J.; Spellmann, H.; Zingg, A. Comparison between the productivity of pure and mixed stands of Norway spruce and European beech along an ecological gradient. Ann. For. Sci. 2010, 67, 712. [CrossRef]

31. Griess, V.C.; Knoke, T. Growth performance, windthrow, and insects: Meta-analyses of parameters influencing performance of mixed-species stands in boreal and northern temperate biomes. Can. J. For. Res. 2011, 41, 1141-1159. [CrossRef]

32. Harris, A.S. Picea sitchensis (Bong.) Carr. Sitka spruce. In Silvics of North America; Burns, R.M., Honkala, B.H., Eds.; USDA Forest Service: Washington, DC, USA, 1990; Volume 1, pp. 260-267.

33. Tesch, S.D. The Pacific Northwest Region. In Regional Silviculture of the United States; Barrett, J.W., Ed.; John Wiley and Sons Inc.: New York, NY, USA, 1995; pp. 499-558.

34. Cordes, L.D. An Ecological Study of the Sitka Spruce Forest on the West Coast of Vancouver Island. Ph.D. Thesis, University of British Columbia, Vancouver, BC, Canada, 1972.

35. Godman, R.M. Seed Dispersal in Southeast Alaska; USDA Forest Service: Juneau, AK, USA, 1953; p. 2.

36. Harris, A.S. Natural Reforestation on a Mile-Square Clearcut in Southeast Alaska; USDA Forest Service, Pacific Northwest Forest and Range Experiment Station: Juneau, AK, USA, 1967; p. 16.

37. Harris, A.S.; Farr, W.A. The Forest Ecosystem of Southeast Alaska; USDA Forest Service, Pacific Northwest Forest and Range Experiment Station: Portland, OR, USA, 1974; p. 109.

38. Deal, R.L.; Oliver, C.D.; Bormann, B.T. Reconstruction of mixed hemlock-spruce stands in coastal southeast Alaska. Can. J. For. Res. 1991, 21, 643-654. [CrossRef] 
39. Orlikowska, E.H.; Deal, R.L.; Hennon, P.E.; Wipfli, M.S. The role of red alder in riparian forest structure along headwater streams in southeastern Alaska. Northwest Sci. 2004, 78, 111-123.

40. Packee, E.C. Tsuga heterophyla (Raf.) Sarg. Western hemlock. In Silvics of North America; Burns, R.M., Honkala, B.H., Eds.; USDA Forest Service: Washington, DC, USA, 1990; Volume 1, pp. 613-622.

41. Deal, R.L.; Farr, W.A. Composition and development of conifer regeneration in thinned and unthinned natural stands of western hemlock and Sitka spruce in southeast Alaska. Can. J. For. Res. 1994, 24, 976-984. [CrossRef]

42. Minore, D. Comparative Autoecological Characteristics of Northwestern Tree Species-A Literature Review; USDA Forest Service, Pacific Northwest Forest and Range Experiment Station: Portland, OR, USA, 1979.

43. Minore, D. Germination and Early Growth of Coastal Tree Species on Organic Seed Beds; USDA Forest Service, Pacific Northwest Forest and Range Experiment Station: Portland, OR, USA, 1972; p. 40.

44. Harmon, M.E.; Franklin, J.F. Tree seedlings on logs in Picea-Tsuga forests of Oregon and Washington. Ecology 1989, 70, 48-59. [CrossRef]

45. Christy, E.J.; Mack, R.N. Variation in demography of juvenile Tsuga heterophylla across the substratum mosaic. J. Ecol. 1984, 72, 75-91. [CrossRef]

46. Levy, L.S.Y.L.; Deal, R.L.; Tappeiner, J.C. The Density and Distribution of Sitka Spruce and Western Hemlock Seedling Banks in Partially Harvested Stands in Southeast Alaska; USDA Forest Service, Pacific Northwest Research Station: Portland, OR, USA, 2010; p. 20.

47. Harrington, C.A. Alnus rubra Bong.-Red alder. In Silvics of North America; Burns, R.M., Honkala, B.H., Eds.; USDA Forest Service: Washington, DC, USA, 1990; Volume 2, pp. 116-123.

48. Hulten, E. Flora of Alaska and Neighboring Territories; Stanford University Press: Stanford, CA, USA, 1968; p. 1008.

49. Viereck, L.A.; Little, E.L. Alaska Trees and Shrubs; U.S. Department of Agriculture: Washington, DC, USA, 1972; Volume 410, p. 265.

50. Wipfli, M.S.; Deal, R.L.; Hennon, P.E.; Johnson, A.C.; DeSanto, T.L.; Hanley, T.A.; Schultz, M.E.; Bryant, M.D.; Edwards, R.T.; Orlikowska, E.H.; et al. Managing Young Upland Forest in Southeast Alaska for Wood Products, Wildlife, Aquatic Resources, and Fishes: Problem Analysis and Study Plan; USDA Forest Service, Pacific Northwest Research Station: Portland, OR, USA, 2002; p. 71.

51. Hanley, T.A.; Deal, R.L.; Orlikowska, E.H. Relations between red alder (Alnus rubra Bong.) and understory vegetation in a gradient of mixed hardwood-conifer, young-growth forest. Can. J. For. Res. 2006, 36, 738-748. [CrossRef]

52. Harrington, C.A.; Zasada, J.C.; Allen, E.A. Biology of Red Alder (Alnus rubra Bong.). In The Biology and Management of Red Alder; Hibbs, D.E., DeBell, D.S., Tarrant, R.F., Eds.; Oregon State University Press: Corvallis, OR, USA, 1994; pp. 3-22.

53. Meier, E. The Wood Database: The Truth behind Wood Identification. 2008. Available online: http:/ / www.wood-database.com/wood-articles/the-truth-behind-wood-identification/ (accessed on 12 September 2016).

54. Ruth, R.H.; Harris, A.S. Management of Western Hemlock-Sitka spruce Forests for Timber Production; USDA Forest Service: Washington, DC, USA, 1979; p. 197.

55. Farr, W.A. Site Index and Height Growth Curves for Unmanaged Even-Aged Stands of Western Hemlock and Sitka Spruce in Southeast Alaska; USDA Forest Service, Pacific Northwest Forest and Range Experiment Station: Portland, OR, USA, 1984; p. 26.

56. Van Pelt, R. Forest Giants of the Pacific Coast, 1st ed.; University of Washington Press: Seattle, WA, USA, 2001; p. 200.

57. Taylor, R.F. Yield of Second-Growth Western Hemlock-Sitka Spruce Stands in South-Eastern Alaska; USDA: Washington, DC, USA, 1934; p. 29.

58. Harris, A.S.; Ruth, R.H. Sitka Spruce: A Bibliography with Abstracts; USDA Forest Service, Pacific Northwest Forest and Range Experiment Station: Portland, OR, USA, 1970; p. 251.

59. Ruth, R.H. Sitka spruce (Picea sitchensis (Bong.) Carr.). In Silvics of Forest Trees of the United States; Folwells, H.A., Ed.; USDA: Washington, DC, USA, 1965; pp. 311-317.

60. Griggs, R.F. The edge of the forest in Alaska and the reason for its position. Ecology 1934, 15, 80-96. [CrossRef]

61. Tappeiner, J.C.; Maguire, D.A.; Harrington, T.B. Silviculture and Ecology of Western U.S. Forests, 1st ed.; Oregon State University Press: Corvallis, OR, USA, 2007; p. 440. 
62. Farr, W.A.; Harris, A.S. Site index of Sitka spruce along the Pacific coast related to latitude and temperatures. For. Sci. 1979, 25, 145-153.

63. Fujimori, T. Primary Productivity of a Young Tsuga Heterophylla Stand and Some Speculations about Biomass of Forest Communities on the Oregon Coast; USDA Forest Service, Pacific Northwest Forest and Range Experiment Station: Portland, OR, USA, 1971; p. 11.

64. Handley, D.L. The yield potential of western hemlock. In Western Hemlock Management; Institute of Forest Products Contribution No. 34; Atkinson, W.A., Zasoski, R.J., Eds.; University of Washington: Seattle, WA, USA, 1976; pp. 221-227.

65. Hibbs, D.E.; DeBell, D.S.; Tarrant, R.F. The Biology and Management of Red Alder, 1st ed.; Hibbs, D.E., DeBell, D.S., Tarrant, R.F., Eds.; Oregon State University Press: Corvallis, OR, USA, 1994; p. 256.

66. Harrington, C.A. A Method of Site Quality Evaluation for Red Alder; USDA Forest Service, Pacific Northwest Research Station: Portland, OR, USA, 1986; p. 22.

67. Heebner, C.F.; Bergener, M.J. Red Alder: A Bibliography with Abstracts; USDA Forest Service, Pacific Northwest Research Station: Portland, OR, USA, 1983; p. 186.

68. Eyre, F.H. Forest Cover Types of the United States and Canada; Society of American Foresters: Washington, DC, USA, 1980; p. 148.

69. Newton, M.; Cole, E.C. Stand development and successional implications: Pure and mixed stands. In The Biology and Management of Red Alder, 1st ed.; Hibbs, D.E., DeBell, D.S., Tarrant, R.F., Eds.; Oregon State University Press: Corvallis, OR, USA, 1994; pp. 106-115.

70. DeMars, D. Stand Density Study of Spruce-Hemlock Stands in Southeastern Alaska; USDA Forest Service, Pacific Northwest Research Station: Portland, OR, USA, 2000; p. 60.

71. Harrington, C.A.; Curtis, R.O. Height Growth and Site Index Curves for Red Alder; USDA Forest Service, Pacific Northwest Research Station: Portland, OR, USA, 1986; p. 14.

72. Worthington, N.P.; Johnson, F.A.; Staebler, G.R.; Lloyd, W.J. Normal Yield Tables for Red Alder; USDA Forest Service, Pacific Northwest Research Station: Portland, OR, USA, 1960; p. 32.

73. Green, R.N.; Klinka, K. A Field Guide to Site Identification and Interpretation for the Vancouver Forest Region; British Columbia Ministry of Forests: Victoria, BC, Canada, 1994; p. 285.

74. Omule, S. Comparative Height Growth to Age 28 for Seven Species in the CWHd Subzone; British Columbia Ministry of Forests: Victoria, BC, Canada, 1987; p. 9.

75. Williamson, R.L. Productivity of Red Alder in Western Oregon and Washington. In Biology of Alder; Trappe, J.M., Franklin, J.E., Tarrant, R.E., Hansen, G.M., Eds.; USDA Forest Service, Pacific Northwest Forest and Range Experiment Station: Portland, OR, USA, 1968; pp. 287-292.

76. Hermann, R.K.; Lavender, D.P. Pseudotsuga menziesii (Mirb.) Franco-Douglas-fir. In Silvics of North America; Burns, R.M., Honkala, B.H., Eds.; USDA Forest Service: Washington, DC, USA, 1990; Volume 1, pp. 527-540.

77. Deal, R.L. Red alder stand development and dynamics. In Red Alder: A State of Knowledge; Deal, R.L., Harrington, C.A., Eds.; USDA Forest Service, Pacific Northwest Research Station: Portland, OR, USA, 2006; pp. $45-54$.

78. DeBell, D.S.; Strand, R.F.; Reukema, D.L. Short-rotation production of red alder: Some options for future forest management. In Utilization and Management of Alder; Briggs, D.G., DeBell, D.S., Atkinson, W.A., Eds.; USDA Forest Service, Pacific Northwest Research Station: Portland, OR, USA, 1978; pp. 231-244.

79. Chambers, C.J. Empirical Yield Tables for Predominantly Alder Stands in Western Washington; Washington State Department of Natural Resources: Olympia, WA, USA, 1983; Volume 31, p. 70.

80. Skinner, E.C. Cubic Volume Tables for Red Alder and Sitka Spruce; USDA Forest Service, Pacific Northwest Research Station: Portland, OR, USA, 1959; p. 4.

81. Bormann, B.T.; Gordon, J.C. Stand Density Effects in Young Red Alder Plantations: Productivity, Photosynthate Partitioning, and Nitrogen Fixation. Ecology 1984, 65, 394-402. [CrossRef]

82. DeBell, D.S.; Giordano, P.A. Growth patterns of red alder. In The Biology and Management of Red Alder, 1st ed.; Hibbs, D.E., DeBell, D.S., Tarrant, R.F., Eds.; Oregon State University Press: Corvallis, OR, USA, 1994; pp. 116-130.

83. Knowe, S.A.; Hibbs, D.E. Stand structure and dynamics of young red alder as affected by planting density. For. Ecol. Manag. 1996, 82, 69-85. [CrossRef]

84. Puettmann, K.J. Growth and yield of red alder. In The Biology and Management of Red Alder, 1st ed.; Hibbs, D.E., DeBell, D.S., Tarrant, R.F., Eds.; Oregon State University Press: Corvallis, OR, USA, 1994; pp. $229-242$. 
85. Knowe, S.A.; Ahrens, G.R.; DeBell, D.S. Comparison of diameter-distribution-prediction, stand-tableprojection, and individual-tree-growth modeling approaches for young red alder plantations. For. Ecol. Manag. 1997, 98, 49-60. [CrossRef]

86. Smith, J.H.G. Growth and yield of red alder in British Columbia. In Biology of Alder; Trappe, J.M., Franklin, J.F., Tarrant, R.F., Hansen, G.M., Eds.; USDA Forest Service, Pacific Northwest Range and Experiment Station: Portland, OR, USA, 1968; pp. 273-286.

87. Gomi, T.; Johnson, A.C.; Deal, R.L.; Hennon, P.E.; Orlikowska, E.H.; Wipfli, M.S. Factors affecting distribution of wood, detritus, and sediment in headwater streams draining managed young-growth red alder-conifer forests in southeast Alaska. Can. J. For. Res. 2006, 36, 725-737. [CrossRef]

88. Deal, R.L.; Hennon, P.E.; Orlikowska, E.H.; D'Amore, D.V. Stand dynamics of mixed red alder-conifer forests of southeast Alaska. Can. J. For. Res. 2004, 34, 969-980. [CrossRef]

89. Kimbirauskas, R.K.; Merritt, R.W.; Wipfli, M.S.; Hennon, P.E. Headwater macroinvertebrate community response to riparian red alder (Alnus rubra Bong.) in southeast Alaska. Pan Pac. Entomol. 2008, 84, 220-237. [CrossRef]

90. Wipfli, M.S.; Deal, R.L.; Hennon, P.E.; Johnson, A.C.; Edwards, R.T.; De Santo, T.L.; Gomi, T.; Orlikowska, E.H.; Bryant, M.D.; Schultz, M.E.; et al. Compatible management of red alder-conifer ecosystems in southeastern Alaska. In Compatible Forest Management, 1st ed.; Monserud, R.A., Haynes, R.W., Johnson, A.C., Eds.; Springer: Dordrecht, The Netherlands, 2003; pp. 55-81.

91. Schultz, M.E.; De Santo, T.L. Comparison of terrestrial invertebrate biomass and richness in young mixed red alder-conifer, young conifer, and old conifer stands of southeast Alaska. Northwest Sci. 2006, 80, 120-132.

92. Bryant, M.D.; Zymonas, N.D.; Wright, B.E. Salmonids on the Fringe: Abundance, Species Composition, and Habitat Use of Salmonids in High-Gradient Headwater Streams, Southeast Alaska. Trans. Am. Fish. Soc. 2004, 133, 1529-1538. [CrossRef]

93. Hibbs, D.E.; Bower, A.L. Riparian forests in the Oregon Coast Range. For. Ecol. Manag. 2001, 154, $201-213$. [CrossRef]

94. Alaback, P.B. Plant Succession Following Logging in the Sitka Spruce-Western Hemlock Forests of Southeast Alaska: Implications for Management; USDA Forest Service, Pacific Northwest Forest and Range Experiment Station: Portland, OR, USA, 1984; p. 26.

95. Miller, R.E.; Murray, M.D. The Effect of Red Alder on Growth of Douglas-Fir. In Utilization and Management of Alder; Briggs, D.G., DeBell, D.S., Atkinson, W.A., Eds.; USDA Forest Service, Pacific Northwest Research Station: Portland, OR, USA, 1978; pp. 283-306.

96. Bormann, B.T.; Cromack, K.; Russell, W.O. Influences of Red Alder on Soils and Long-Term Ecosystem Productivity. In The Biology and Management of Red Alder, 1st ed.; Hibbs, D.E., DeBell, D.S., Tarrant, R.F., Eds.; Oregon State University Press: Corvallis, OR, USA, 1994; pp. 47-56.

97. Bryant, M.D. Changes thirty years after logging in large woody debris, and its use by salmonids. In Riparian Ecosystems and Their Management: Reconciling Conflicting Uses; Johnson, R.R., Ziebell, C.D., Patton, D.R., Folliott, P.F., Hamre, R.H., Eds.; USDA Forest Service, Rocky Mountain, Forest and Range Experiment Station: Fort Collins, CO, USA, 1985; pp. 329-334.

98. Bisson, P.A.; Bilby, R.E.; Bryant, M.D.; Dollof, C.A.; Grette, G.B.; House, R.A.; Murphy, M.L.; Koski, K.V.; Sedell, J.R. Large Woody Debris in the Pacific Northwest: Past, Present, and Future. In Streamside Management: Forestry and Fishery Interactions; Salo, E.O., Cundy, T.W., Eds.; Institute of Forest Resources, University of Washington: Seattle, WA, USA, 1987; pp. 143-190.

99. Minore, D.; Weatherly, H.G. Riparian trees, shrubs and forest regeneration in the coastal mountains of Oregon. New For. 1994, 8, 249-263. [CrossRef]

100. Nierenberg, T.R.; Hibbs, D.E. A characterization of unmanaged riparian areas in the central Coast Range of western Oregon. For. Ecol. Manag. 2000, 129, 195-206. [CrossRef]

101. Pabst, R.J.; Spies, T.A. Structure and composition of unmanaged riparian forests in the coastal mountains of Oregon, USA. Can. J. For. Res. 1999, 29, 1557-1573. [CrossRef]

102. Hennon, P.E.; McClellan, M.H. Tree mortality and forest structure in the temperate rain forests of southeast Alaska. Can. J. For. Res. 2003, 33, 1621-1634. [CrossRef]

103. Kessler, W.B.; Kogut, T.E. Habitat orientations of forest birds in southeastern Alaska. Northwest Sci. 1985, 59, $58-65$. 
104. Schwab, F.E. Effect of Vegetation Structure on Breeding Bird Communities in the Dry Zone Douglas-Fir Forests of Southeastern British Columbia. Master's Thesis, University of British Columbia, Vancouver, BC, Canada, 1979.

105. Huff, M.H.; Raley, C.M. Regional Patterns of Diurnal Breeding Bird Communities in Oregon and Washington. In Wildlife and Vegetation of Unmanaged Douglas-Fir Forests; Ruggiero, L.F., Aubry, K.B., Carey, A.B., Huff, M.H., Eds.; USDA Forest Service, Pacific Northwest Research Station: Portland, OR, USA, 1991; pp. 177-206.

106. Gilbert, F.F.; Allwine, R. Spring bird communities in the Oregon Cascade Range. In Wildife and Vegetation of Unmanaged Douglas-Fir Forests; Ruggiero, L.F., Aubry, K.B., Carey, A.B., Huff, M.H., Eds.; USDA Forest Service, Pacific Northwest Research Station: Portland, OR, USA, 1991; pp. 145-160.

107. McComb, W.C. Red alder: Interactions with wildlife. In The Biology and Management of Red Alder, 1st ed.; Hibbs, D.E., DeBell, D.S., Tarrant, R.F., Eds.; Oregon State University Press: Corvallis, OR, USA, 1994; pp. 131-138.

108. Kelly, J.P. The effect of nest predation on habitat selection by dusky flycatchers in limber pine-juniper woodland. Condor 1993, 95, 83-93. [CrossRef]

109. Martin, T.E. Nest predation among vegetation layers and habitat types: Revising the dogmas. Am. Nat. 1993, 141, 898-913. [CrossRef] [PubMed]

110. Easton, W.E.; Martin, K. Effects of thinning and herbicide treatments on nest-site selection by songbirds in young managed forests. Auk 2002, 119, 685-694. [CrossRef]

111. Airola, D.A. Foraging and Habitat Relations of Insectivorous Birds in a Managed Sierra Nevada Mixed Conifer Forest. Master's Thesis, University of California, Berkeley, CA, USA, 1979.

112. Holmes, R.T. The structure of a temperate deciduous forest bird community: Variability in time and space. In Biogeography and Ecology of Forest Bird Communities, 1st ed.; Keast, A., Ed.; SPB Publishing: Hague, The Netherlands, 1990; pp. 121-139.

113. Stiles, E.W. Bird community structure in alder forests in Washington. Condor 1980, 82, 20-30. [CrossRef]

114. Willson, M.F.; Comet, T.A. Bird communities of northern forests: Patterns of diversity and abundance. Condor 1996, 98, 337-349. [CrossRef]

115. Wipfli, M.S.; Musslewhite, J. Density of red alder (Alnus rubra) in headwaters influences invertebrate and detritus subsidies to downstream fish habitats in Alaska. Hydrobiologia 2004, 520, 153-163. [CrossRef]

116. Cummins, K.W.; Wilzbach, M.A.; Gates, D.M.; Taliaferri, J.B.; Perry, W.B. Shredders and riparian vegetation: Leaf litter that falls into streams influences communities of stream invertebrates. BioScience 1989, 39, 24-30. [CrossRef]

117. Wipfli, M.S. Terrestrial invertebrates as salmonid prey and nitrogen sources in streams: Contrasting old-growth and young-growth riparian forests in southeastern Alaska, U.S.A. Can. J. Fish. Aquat. Sci. 1997, 54, 1259-1269. [CrossRef]

118. Mason, C.F.; Macdonald, S.M. The input of terrestrial invertebrates from tree canopies to a stream. Freshw. Biol. 1982, 12, 305-311. [CrossRef]

119. Piccolo, J.J.; Wipfli, M.S. Does red alder (Alnus rubra) in upland riparian forests elevate macroinvertebrate and detritus export from headwater streams to downstream habitats in southeastern Alaska? Can. J. Fish. Aquat. Sci. 2002, 59, 503-513. [CrossRef]

120. Allan, J.D.; Wipfli, M.S.; Caouette, J.P.; Prussian, A.; Rodgers, J. Influence of streamside vegetation on terrestrial invertebrate subsidies to salmonid food webs. Can. J. Fish. Aquat. Sci. 2003, 60, 309-320. [CrossRef]

121. Luken, J.O.; Fonda, R.W. Nitrogen accumulation in a chronosequence of red alder communities along the Hoh River, Olympic National Park, Washington. Can. J. For. Res. 1983, 13, 1228-1237. [CrossRef]

122. Fevold, K. Sub-Surface Controls on the Distribution of Benthic Algae in Floodplain Back Channel Habitats of the Queets River. Master's Thesis, University of Washington, Seattle, WA, USA, 1998.

123. Benda, L.E.; Dunne, T. Stochastic forcing of sediment routing and storage in channel networks. Water Resour. Res. 1997, 33, 2865-2880. [CrossRef]

124. Gomi, T.; Sidle, R.C.; Richardson, J.S. Understanding processes and downstream linkages of headwater systems. BioScience 2002, 52, 905-916. [CrossRef]

125. Gregory, S.V.; Swanson, F.J.; McKee, W.A.; Cummins, K.W. An ecosystem perspective of riparian zones. BioScience 1991, 41, 540-551. [CrossRef]

126. Swanson, F.J.; Johnson, S.L.; Gregory, S.V.; Acker, S.A. Flood disturbance in a forested mountain landscape. BioScience 1998, 48, 681-689. [CrossRef] 
127. Wipfli, M.S.; Gregovich, D.P. Export of invertebrates and detritus from fishless headwater streams in southeastern Alaska: Implications for downstream salmonid production. Freshw. Biol. 2002, 47, 957-969. [CrossRef]

128. Hanley, T.A.; Barnard, J.C. Red alder, Alnus rubra, as a potential mitigating factor for wildlife habitat following clearcut logging in southeastern Alaska. Can. Field Nat. 1998, 112, 647-652.

129. Newton, M.; El Hassan, B.A.; Zavitkovski, J. Role of red alder in western Oregon forest succession. In Biology of Alder; Trappe, J.M., Franklin, J.E., Tarrant, R.E., Hansen, G.M., Eds.; USDA Forest Service, Pacific Northwest Forest and Range Experiment Station: Portland, OR, USA, 1968; pp. 73-84.

130. Deal, R.L.; Russell, J.M. The potential role of red alder for restoring forest ecosystems in even-aged western hemlock-Sitka spruce stands of southeast Alaska. In Integrated Restoration of Forested Ecosystems to Achieve Multi-Resource Benefits: Proceedings of the 2007 National Silviculture Workshop; Deal, R.L., Ed.; USDA Forest Service, Pacific Northwest Research Station: Portland, OR, USA, 2008; pp. 135-145.

131. Deal, R.L.; Tappeiner, J.C. The effects of partial cutting on stand structure and growth of western hemlock-Sitka spruce stands in southeast Alaska. For. Ecol. Manag. 2002, 159, 173-186. [CrossRef]

132. Newton, M.E.; Cole, E.C.; White, D.E. Tall planting stock for enhanced growth and domination of brush in the Douglas-fir region. New For. 1993, 7, 107-121. [CrossRef]

133. O'Hanlon, R.; Harrington, T.J.; Outerbridge, R.A.; Berch, S.M. High species richness but different communities of macrofungi in Sitka spruce (Picea sitchensis [Bong. Carr.]) forests in its native (British Columbia) and non-native (Ireland and Britain) range. Can. J. For. Res. 2013, 43, 450-458. [CrossRef]

134. Alaback, P.B. Dynamics of Understory Biomass in Sitka Spruce-Western Hemlock Forests of Southeast Alaska. Ecology 1982, 63, 1932-1948. [CrossRef]

135. Tappeiner, J.C., II; Alaback, P.B. Early establishment and vegetative growth of understory species in the western hemlock-Sitka spruce forests in southeast Alaska. Can. J. Bot. 1989, 67, 318-326. [CrossRef]

136. Doerr, J.G.; Sandburg, N.H. Effects of precommercial thinning on understory vegetation and deer habitat utilization on Big Level Island in Southeast Alaska. For. Sci. 1986, 32, 1092-1095.

137. Parker, K.L.; Gillingham, M.P.; Hanley, T.A.; Robbins, C.T. Energy and protein balance of free-ranging black-tailed deer in a natural forest environment. Wildl. Monogr. 1999, 143, 1-48.

138. Hanley, T.A.; McKendrick, J.D. Seasonal Changes in Chemical Composition and Nutritive Value of Native Forages in a Spruce-Hemlock Forest, Southeastern Alaska; USDA Forest Service, Pacific Northwest Forest and Range Experiment Station: Portland, OR, USA, 1983; p. 48.

139. Hanley, T.A.; Barnard, J.C. Food resources and diet composition in riparian and upland habitats for Sitka mice, Peromyscus keeni sitkensis. Can. Field Nat. 1999, 113, 401-407.

140. Franklin, J.F. Scientific Basis for New Perspectives in Forests and Streams. In Watershed Management; Naiman, R., Ed.; Springer: New York, NY, USA, 1992; pp. 25-72.

141. Hernandez, O.; Merritt, R.W.; Wipfli, M.S. Benthic invertebrate community structure is influenced by forest succession after clearcut logging in southeastern Alaska. Hydrobiologia 2005, 533, 45-59. [CrossRef]

142. Hanley, T.A. Small mammals of even-aged, red alder-conifer forests in southeastern Alaska. Can. Field Nat. 1996, 110, 626-629.

143. Deal, R.L. Understory Plant Diversity in Riparian Alder-Conifer Stands after Logging in Southeast Alaska; US Department of Agriculture, Forest Service, Pacific Northwest Research Station: Portland, OR, USA, 1997; p. 8.

144. Pechanec, A.A.; Franklin, J.F. Comparison of vegetation in adjacent alder, conifer, and mixed alder-conifer communities. II. Epiphytic, epixylic, and epilithic cryptogam. In Biology of Alder; Trappe, J.M., Franklin, J.F., Tarrant, R.F., Hansen, G.M., Eds.; USDA Forest Service, Pacific Northwest Forest and Range Experiment Station: Portland, OR, USA, 1968; pp. 85-98.

145. Beechie, T.J.; Pess, G.; Kennard, P.; Bilby, R.E.; Bolton, S. Modeling Recovery Rates and Pathways for Woody Debris Recruitment in Northwestern Washington Streams. N. Am. J. Fish. Manag. 2000, 20, 436-452. [CrossRef]

146. Tarrant, R.F.; Bormann, B.T.; DeBell, D.S.; Atkinson, W.A. Managing red alder in the Douglas-fir region: Some possibilities. J. For. 1983, 81, 787-792.

147. Murai, S. Phytotaxomomical and Geobotanical Studies on Genus Alnus in Japan. III. Taxonomy of Whole World Species and Distribution of Each Sect; Government Forest Experiment Station Bulletin: Tokyo, Japan, 1964; Volume 171, pp. 1-107. 
148. Fahlvik, N.; Agestam, E.; Ekö, P.M.; Linden, M. Development of single-storied mixtures of Norway spruce and birch in Southern Sweden. Scan. J. For. Res. 2011, 26, 36-45. [CrossRef]

149. Webster, C.R.; Lorimer, C.G. Single-tree versus group selection in hemlock-hardwood forests: Are smaller openings less productive? Can. J. For. Res. 2002, 32, 591-604. [CrossRef]

150. Boncina, A.; Gaspersic, F.; Diaci, J. Long-term changes in tree species composition in the Dinaric mountain forests of Slovenia. For. Chron. 2003, 79, 227-232. [CrossRef] 